\title{
Geoarchaeology of Pleistocene open-air sites in the Vila Nova da Barquinha-Santa Cita area (Lower Tejo River basin, central Portugal)
}

\author{
António A. Martins ${ }^{\mathrm{a}, *}$, Pedro P. Cunha ${ }^{\mathrm{b}}$, Pierluigi Rosina ${ }^{\mathrm{c}}$, Luiz Osterbeek ${ }^{\mathrm{c}}$, Sara Cura ${ }^{\mathrm{d}}$, \\ Stefano Grimaldi ${ }^{\mathrm{e}}$, José Gomes ${ }^{\mathrm{f}}$, Jan-Pieter Buylaert ${ }^{\mathrm{g}}$, Andrew S. Murray ${ }^{\mathrm{g}}$, João Matos ${ }^{\mathrm{h}}$ \\ ${ }^{a}$ Centro de Geofísica, Dep. Geociências University Évora, Portugal \\ ${ }^{\mathrm{b}}$ Dep. of Earth Sciences, Marine and Environmental Research Centre, Univ. Coimbra, Portugal \\ ' Instituto Politécnico de Tomar, Centro de Geociências Univ. Coimbra, Portugal \\ d Museu de Arte Pré-Histórica de Mação, Centro de Geociências Univ. Coimbra, Portugal \\ ${ }^{\mathrm{e}}$ Universitá degli Studi di Trento, Centro de Geociências Univ. Coimbra, Portugal \\ ${ }^{\mathrm{f}}$ Centro de Interpretação de Arqueologia do Alto Ribatejo, Centro de Geociências Univ. Coimbra, Portugal \\ ${ }^{\mathrm{g}}$ Nordic Laboratory for Luminescence Dating, Aarhus Univ., Risø DTU, Denmark \\ ${ }^{\mathrm{h}}$ Bolseiro BIC (proj. POCI/CTE-GEX/58120/2004), Dep. Geociências Univ. Évora, Portugal
}

\section{A R T I C L E I N F O}

\section{Article history:}

Received 14 April 2009

Received in revised form 25 August 2009

Accepted 21 January 2010

Available online 19 February 2010

\section{Keywords:}

Palaeolithic

Pleistocene

Luminescence dating

Terraces

Tejo River

Iberia

\begin{abstract}
A B S T R A C T
This paper aims to provide insight into human occupation and landscape change during the Pleistocene in a central area of the Lower Tejo basin (Portugal). Detailed geomorphological mapping, coupled with lithostratigraphy, sedimentology and luminescence dating, supports the identification of a complete terrace staircase sequence. It consists of six gravely terraces located below the culminant (Pliocene) basin unit. A chronological framework for the sedimentary sequences and associated human industries is proposed and correlated with marine oxygen isotope stages (MIS): T1 terrace, not dated; T2, not dated; T3, >300 ka; T4, 300-160 ka (MIS8, MIS7 and MIS6); T5, 136-75 ka (MIS5); T6, 62-30 ka (MIS3); colluvium and aeolian sands, $\sim 30-14 \mathrm{ka}$ (MIS2); valley fill deposits, $\sim 14$ ka to present (MIS1). The oldest artefacts were found at the base of the T4 terrace, with the local stratigraphic level dated to $\geq 175 \pm 6 \mathrm{ka}$ (Middle Pleistocene). The lithic assemblages collected from distinct stratigraphic levels (T4, T5 top, T6 terraces and colluvium) are characterized by the predominance of opportunistic technological choices, a feature that can be attributed partly to the preferential exploitation of the available raw material, dominated by local-sourced quartzites and quartz pebbles. The adaptation to local raw material (texture and volume), together with subsistence patterns and behaviours, could explain the rarity of Acheulian types (handaxes and cleavers) and picks in the T4 terraces of the Tejo tributaries; this is in contrast to the same terrace of the Tejo valley, in which these types are found. Interpretation of the environmental conditions (controlled by climate and glacio-eustatic sea-level changes) affecting the hunter-gatherer human groups is also presented.
\end{abstract}

(c) 2010 The Geologists' Association. Published by Elsevier Ltd. All rights reserved.

\section{Introduction}

The Iberian Peninsula is influenced by both the Atlantic and Mediterranean domains. Pleistocene fluvial terrace sequences are well developed in most of the major river systems in Iberia, with many of them driven by climate changes, although tectonic and sea-level effects can also be observed (Bridgland and Westaway, 2007; Santisteban and Schulte, 2007).

The $\sim 1100 \mathrm{~km}$ long Tejo River originates in central-eastern Spain at an altitude of $1839 \mathrm{~m}$ and has a catchment area of

\footnotetext{
* Corresponding author at: Departamento de Geociências da Univ. de Évora, Rua Romão Ramalho, 59, 7000-671, Évora, Portugal. Tel.: +351 266745301; fax: +351 266745397.

E-mail address: aam@uevora.pt (A.A. Martins).
}

$81,947 \mathrm{~km}^{2}$ with a present average flow of $\sim 17,253 \mathrm{Hm}^{3} \mathrm{yr}^{-1}$ (Benito et al., 2003). In the Portuguese sector the catchment comprises $\sim 25,000 \mathrm{~km}^{2}$ and the river is $230 \mathrm{~km}$ long, with a mean gradient of $0.03 \%$. Today the river is characterized by extreme seasonal and annual flow variability, with peak discharges more than 30 times the average discharge (Benito et al., 2003; Bettencourt and Ramos, 2003). The Tejo drains two Cenozoic basins (the Madrid and the Lower Tejo basins, respectively) towards the west and southwest. Its mouth, at the Atlantic Ocean, is located near Lisboa (central western Portugal). The Lower Tejo valley provides a long record (ca. 3.4 Ma) of alluvial and cultural history, from which it is possible to interpret landscape development, environmental changes and human occupation, all influenced by base-level and climate changes (Cunha et al., 2005, 2008).

In the Lower Tejo basin, the aggradational terraces consist mainly of coarse-grained siliciclastic gravels and sands (Cunha 


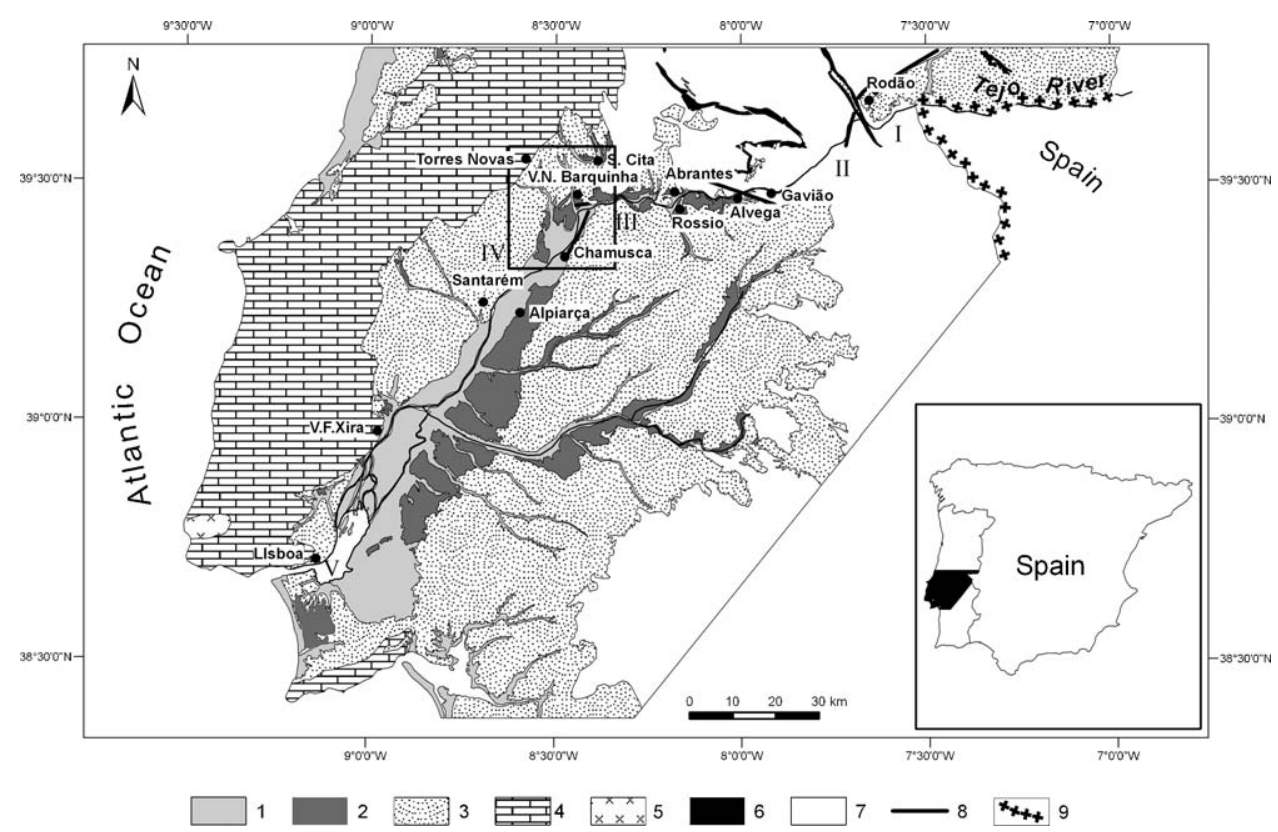

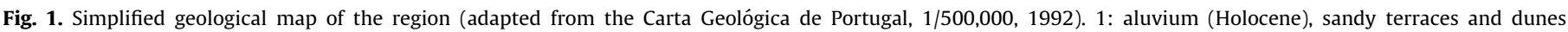

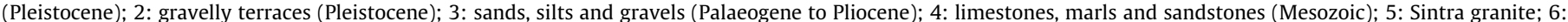

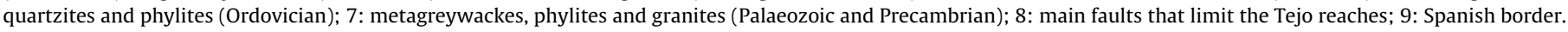

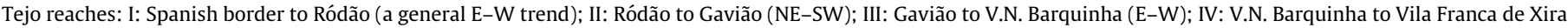
(NNE-SSW); V: V.F. Xira to the Atlantic coast (modern estuary).

et al., 2008; Martins et al., 2009a) which are generally unsuitable for the preservation of organic remains (bones, wood, shells, etc.) due to hydrodynamic and diagenetic processes. This has prevented the widespread use of ${ }^{14} \mathrm{C}$ dating.

Knowledge of the Tejo fluvial network evolution has improved during recent years as more geomorphological, sedimentological, paleontological and geochronological data has become available (e.g. Daveau, 1993; Pérez-González, 1994; Silva et al., 1997; Martins, 1999; Santonja and Pérez-González, 2000-2001; Gutiérrez-Elorza et al., 2002; Silva, 2003; Cunha et al., 1993, 2005, 2008; Bridgland et al., 2006; Santisteban and Schulte, 2007; Ortiz et al., 2009; Martins et al., 2009a). The fluvial sequences of the Tejo River offer wide possibilities for dating as they provide biostratigraphical data that can be compared with instrumental ages (e.g. luminescence and U-series dating) and palaeomagnetic data. However, the chronological framework is a major issue as the range of applications is limited by methodological constraints and the spatial coverage is sparse (Santisteban and Schulte, 2007).

Lower to Upper Palaeolithic artefacts are frequently found in situ in fluvial contexts of the Iberian Peninsula, particularly in systems draining to the Atlantic (e.g. in the terraces of the Douro, Tejo, Guadiana and Guadalquivir rivers; Bridgland et al., 2006). In the Lower Tejo basin, the oldest terrace containing lithic artefacts documents a cultural sequence perceived to range from Clactonian-Abbevilian to Upper Acheulian assemblages (Breuil and Zbyszewski, 1942; Zbyszewski, 1943, 1946, 1958 ) or Lower Acheulian to Micoquian assemblages (Raposo et al., 1985; Ribeiro, 1990; Raposo, 1995a,b). The assemblages considered to be earliest Middle Palaeolithic generally consist of small samples and exhibit continuity with those from the late Lower Palaeolithic (Raposo, 2000). Furthermore, in the study area (Santa Cita-Vila Nova da Barquinha), drained by Tejo tributaries, lithic assemblages show an apparent homogeneity due to the lack of diagnostic implements (Grimaldi et al., 1999a; Cura and Grimaldi, 2009). Alleged similarities among lithic collections made from quartzite, the so-called Languedocian implements (Grimaldi et al., 1998) that are associated with anthropogenic occupations stratigraphically attributed to chronological contexts from middle Pleistocene to Holocene, require an in-depth study aimed at disentangling these similarities (Raposo, 1986; Oosterbeek et al., in press). Until recently, the rare absolute dating of the lower terraces of the Lower Tejo basin strongly limited the chronological attribution of the lithic industries found in these deposits (Raposo, 1995b, 2000).

This paper uses a geoarchaeological approach to obtain a better understanding of the human occupations during the Pleistocene by studying several open-air sites on terraces of the Tejo River and its tributaries in the Vila Nova da Barquinha-Santa Cita area, at the transition of the Portuguese Tejo reaches III to IV (Cunha et al., 2005; Fig. 1). By integrating and analysing a large set of existing and new multidisciplinary data and by relying on a detailed chronological framework supported by luminescence dating, this study provides new insight into the fluvial evolution of the Tejo River and its associated prehistory.

\section{Geographical and geological setting}

The $\sim 200 \mathrm{~km}^{2}$ study area is located in central Portugal. The Tejo reach III is a wide E-W trending valley, usually with terraces although when it crosses basement heights between the tectonic depressions of Alvega, Rossio and Tramagal it becomes locally narrow, without terraces. The Tejo reach IV, with a NNE-SSW trend, has a valley with well developed terraces and a $5-10 \mathrm{~km}$ wide alluvial plain (Martins et al., 2009a) with mixed estuarinefluvial deposits (Vis et al., 2008). Reach IV aggraded under the influence of sea-level, climate and anthropogenic controls, following the sea-level-induced incision of the valley floor during the Last Glacial Maximum (e.g. Dias et al., 2000) or since $\sim 14,000$ yrs cal BP (Vis et al., 2008).

In this region, the Tejo River receives two major tributaries: the Zêzere and the Nabão rivers, which cross the area from north to south (Fig. 2). The drainage system of the Nabão River includes the Bezelga and the Pias streams in the north. In the west, the Ponte da Pedra stream flows directly to the Tejo River. Three archaeological 


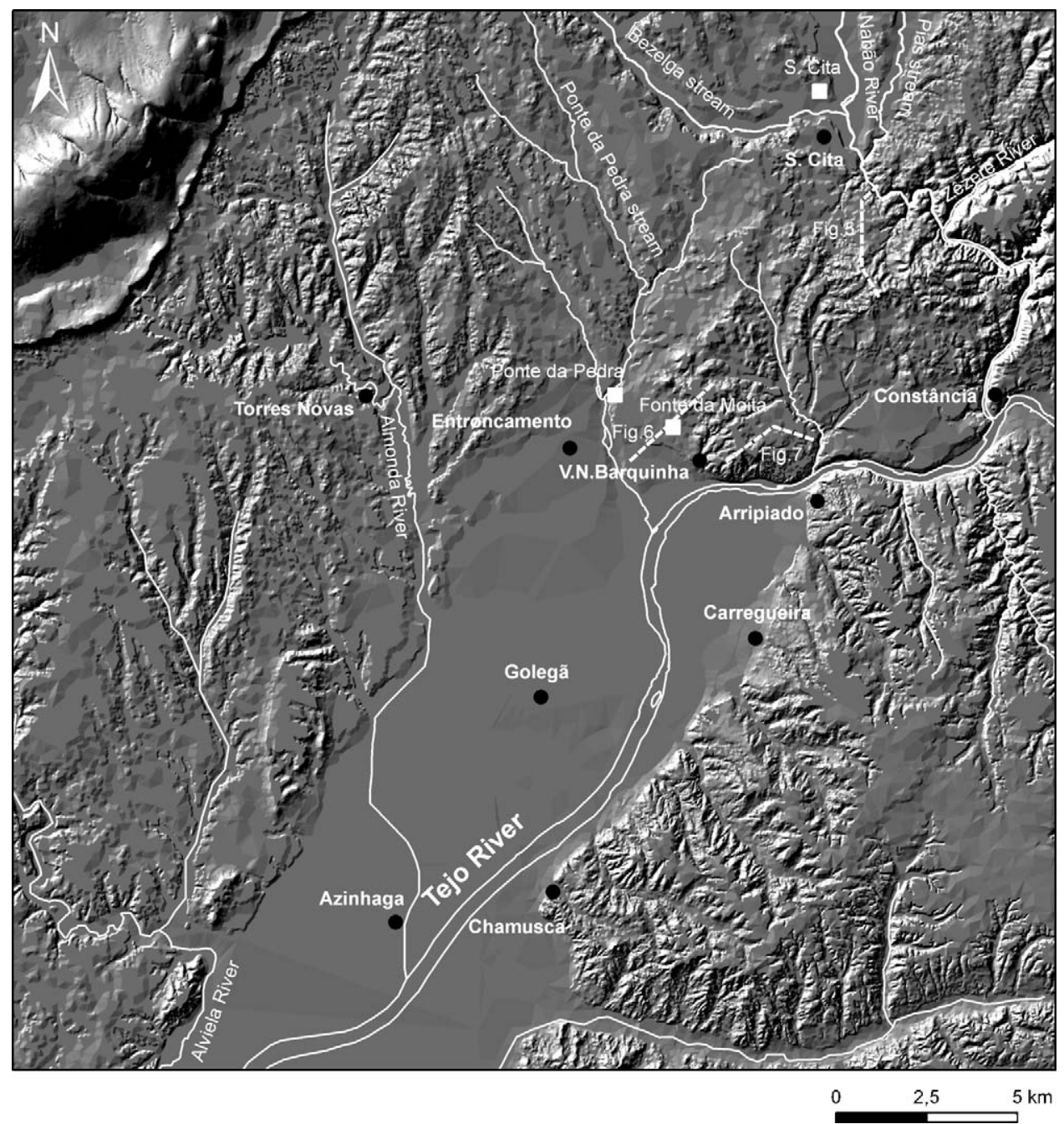

Fig. 2. Digital Terrain Model (DTM) of the study area (10 m resolution; no vertical amplification). Squares: main archaeological sites.

open-air sites, Fonte da Moita, Ponte da Pedra and Santa Cita, have been found in the terraces of the Tejo River or its tributaries.

From the geological perspective, the study area mainly comprises clastic sediments of the Lower Tejo Cenozoic basin (Carvalho, 1968; Cunha, 1992; Cunha et al., 1993; Barbosa, 1995; Martins, 1999; Fig. 3). Mesozoic limestones crop out to the west and a Variscan basement (the Hesperian Massif) to the east and north. The basement comprises Precambrian and Palaeozoic metamorphic rocks, such as phylites, gneisses, amphibolites and quartzites, but also magmatic rocks like granite and filonean quartz. Fluvial terraces constitute the most important Pleistocene deposits in the study area.

The regional relief (Fig. 4) consists of small plateaus and hills that rarely exceed $200 \mathrm{~m}$ in altitude. The slopes are gentle, with the exception of the Hesperian Massif areas, where the incision of the drainage has excavated deep narrow valleys in the resistant Palaeozoic bedrock.

Along the Tejo reach III the landscape is dominated by fluvial landforms created by superimposed transverse drainage onto basement highs that alternate with lows in tectonic depressions containing a soft substratum. From northeast to southwest, the Medroa (270 m), Chorafome (205 m) and Barquinha (150 m) highs alternate with the Martinchel $(150 \mathrm{~m})$, Tancos military airport (77 $\mathrm{m}$ ) and Entroncamento (30 m) lows. A similar sequence can be identified from the Santa Cita to Montalvo lows (northwest to southeast), separated by the Medroa and Chorafome basement highs, crossed in superposition by the Nabão and Zêzere rivers.
Transverse drainage across the basement structure occurs between the depressions of Montalvo and Entroncamento, where the Tejo River crosses the Tancos granite horst. In this structural context, the river has excavated entrenched valleys in the highs of the basement, and built enlargements in the depressions situated immediately upstream (Figs. 3 and 4). Within the depressions, enlargement of the valleys promoted aggradation and the development of fluvial terraces.

\section{Previous studies}

Several fluvial terraces have been identified since $\sim 1940$ in the Portuguese Tejo River valley (Ribeiro, 1943; Breuil and Zbyszewski, 1942, 1945; Zbyszewski, 1953); these were first represented in the 1/50,000 geologic maps as Q1: +95-75 m, Q2: +65-50 m, Q3: +40$25 \mathrm{~m}$ and Q4: $+15-8 \mathrm{~m}$ above the river bed (a.r.b.). Lithic artefacts have been found at the surface and in the stratigraphy of the lower terraces (Q3 and Q4).

A glacio-eustatic model based on the classic Alpine glaciations was used to explain the formation of these terraces and to provide the chronological framework (Zbyszewski, 1943, 1946). Q1 and Q2, the 'upper terraces', were ascribed to the Gunz-Mindel interglacial, or even to the pre-Gunz (Q1), actually designated as Cromerian Complex ( 870-480 ka; e.g. Silva et al., 2009). Q3, the 'middle terrace', was related to the late Mindel to initial Riss, now the Holsteinian ( 420-380 ka) and Q4 ('low terrace') to the RissWürm interglacial, now the Eemian (130-115 ka). At the Vale do 


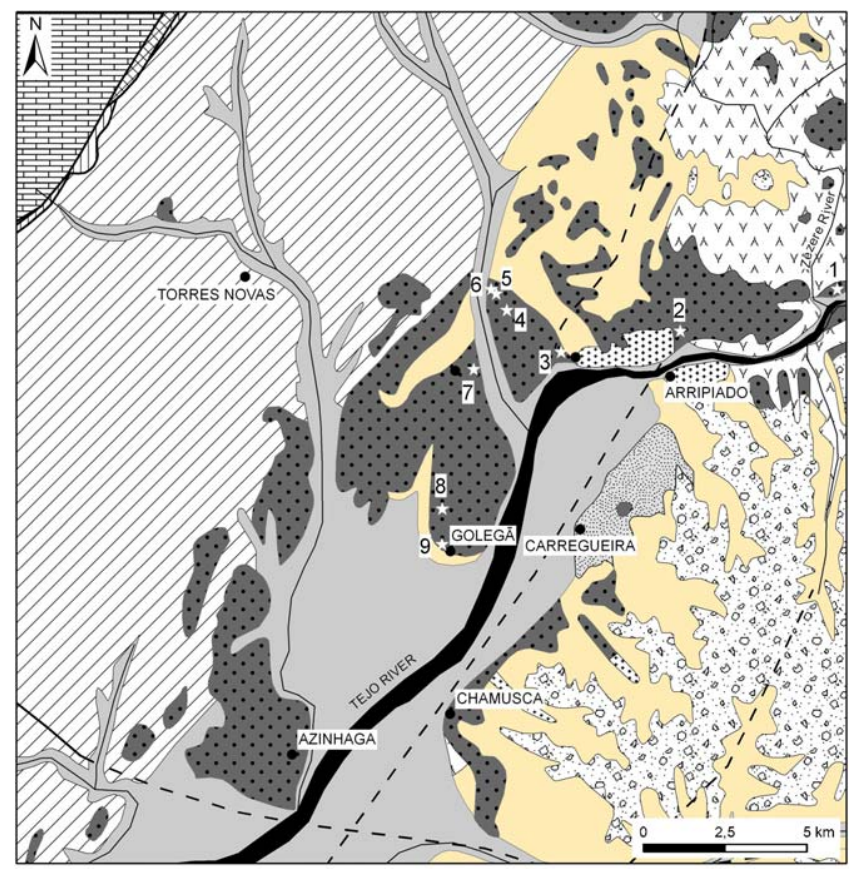

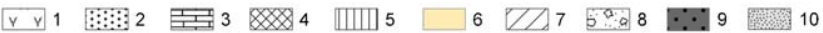

$11-12--13 \star 14$

Fig. 3. Geological map of the study area and adjacent Tejo valley (adapted from 1/50,000 geological maps). 1: gneisses and other metamorphic rocks; 2 : granites; 3: Jurassic (mainly limestones); 4: Cretaceous (sandstones, marls and limestones); 5: Palaeogene (conglomerates, sandstones and clays); 6: Lower to Middle Miocene (sands and clays); 7: Upper Miocene (limestones and marls); 8: Pliocene (gravels and sands); 9: Pleistocene (fluvial terraces; mainly gravels); 10: upper Pleistocene (aeolian sands); 11: Holocene (alluvium); 12: fault; 13: probable fault. Stars: location of dated samples presented in Table 1: 1 : Constância (T4); 2: Tancos (T3); 3: V.N. Barquinha (T4); 4-: Atalaia (T4); 5: Ponte da Pedra (T4); 6: Ponte da Pedra (T5); 7: Entroncamento (T5); 8: Courelas (T6); 9: Golegã (T6).
Forno archaeological site, near Alpiarça, located $40 \mathrm{~km}$ downstream of the study area (Fig. 1), the lithostratigraphy of the Q3 terrace was studied in detail: (a) the Lower Gravels Unit was ascribed to glacial conditions and low stand sea-level; (b) the Upper Sands Unit, comprising a complex of sands and silts, was related to an interglacial period of high sea-level and drier climatic conditions; (c) the gravels at the top were related to a climatic change towards cold conditions. According to the typological features of the handaxes, the industries collected from the Lower Gravels Unit were considered Clactonian-Abbevilian and those from the Upper Sands Unit as representing the Acheulian (Breuil and Zbyszewski, 1942; Zbyszewski, 1946). Later, several stratigraphic levels belonging to the Upper Sands Unit were documented as yielding Middle Acheulian (site VF1), Upper Acheulian (VF8) and Micoquian (equivalent to uppermost Acheulian) industries (VF3) (Raposo et al., 1985; Mozzi et al., 2000; Raposo, 2002). For the Acheulian industries collected from the Upper Sands Unit, these later studies proposed a much more recent chronological framework (late Riss to early Würm, ca. 150-70 ka, an age encompassing MIS5) than that proposed by the traditional interpretation (late Mindel to Initial Riss, ca. 400-300 ka). This interpretation was based on the presence of Micoquian industries (mainly handaxes) at the VF3 site and on three thermoluminescence (TL) dating results from VF8: $117 \mathrm{ka}(-26 \mathrm{ka}+$ infiinfinite), $119 \mathrm{ka}(-32 \mathrm{ka}+$ infinite $)$ and $>124 \mathrm{ka}$. These must however be considered as minimum ages, as the grains were found to be in saturation (indicated by the + infinite uncertainties). Optically stimulated luminescence (OSL) ages from the more upstream reaches of the Tejo River (Cunha et al., 2008; Martins et al., 2009a) suggest that in the Vale do Forno area the T4 terrace has an age ranging from $\geq 240 \mathrm{ka}$ (at its base) to $\sim 150 \mathrm{ka}$ (top). Luminescence dating is needed to clarify the local age of the terrace deposits and associated lithic industries.

Archaeological studies in the Vila Nova da Barquinha area started in the early 1990s, with a series of surveys intended to establish a chronological and techno-typological characterization

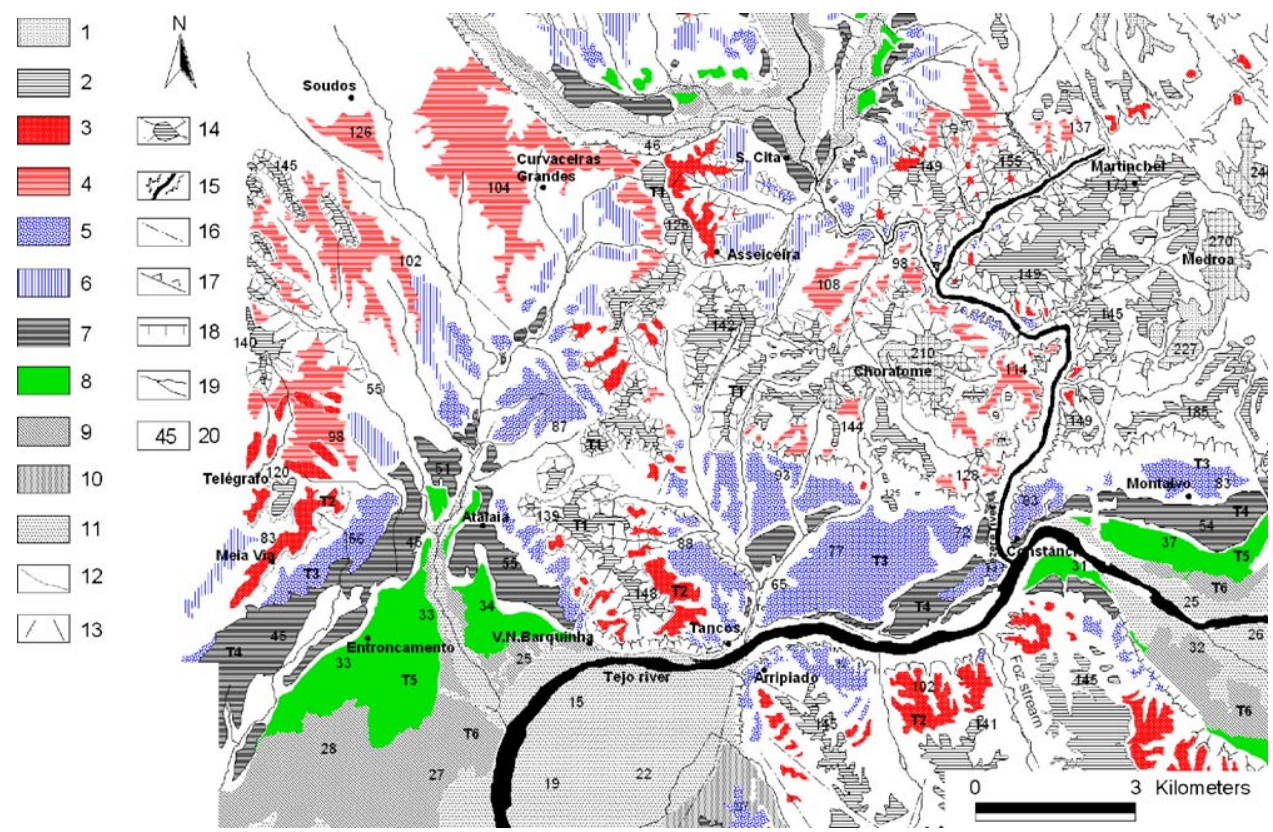

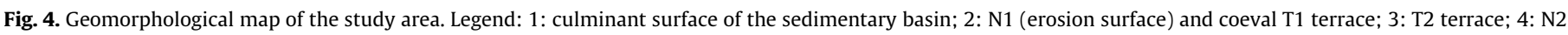

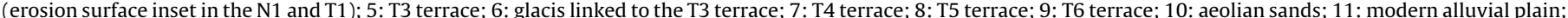

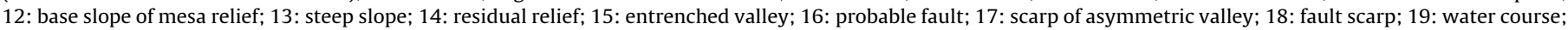
20: altitude (meters). 
Table 1

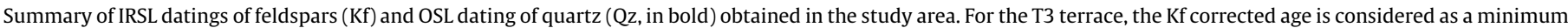
estimate. The ages presented by Martins et al. (2009a) are in italics. See text for additional details.

\begin{tabular}{|c|c|c|c|c|c|c|c|c|c|c|c|}
\hline Lab code & Site name & $\begin{array}{l}\text { Tejo } \\
\text { reach }\end{array}$ & $\begin{array}{l}\text { Altitude } \\
\text { (m) }\end{array}$ & Terrace & Grain size & $\begin{array}{l}\text { Dose } \\
\text { Reco-very }\end{array}$ & $D_{\mathrm{e}}(\mathrm{Gy})$ & $N$ & $\begin{array}{l}\text { Dose rate } \\
(\mathrm{Gy} / \mathrm{ka})\end{array}$ & $\begin{array}{l}\text { Uncorrected } \\
\text { age (ka) }\end{array}$ & $\begin{array}{l}\text { Corrected } \\
\text { age (ka) }\end{array}$ \\
\hline $052236 \mathrm{Kf}$ & Tancos & III & 61 & T3 middle & Coarse sand & $1.02 \pm 0.02$ & $585 \pm 24$ & 6 & $3.4 \pm 0.1$ & $171 \pm 10$ & $\geq 291 \pm 14$ \\
\hline $062208 \mathrm{Kf}$ & Constância & III & 47 & T4 base & Coarse sand & $0.84 \pm 0.01$ & $434 \pm 7$ & 12 & $4.0 \pm 0.1$ & $107 \pm 5$ & $\geq 190 \pm 15$ \\
\hline $062204 \mathrm{Kf}$ & $\begin{array}{l}\text { V.N. Barquinha } \\
\text { (chapel) }\end{array}$ & IV & 59 & T4 top & Medium sand & $0.99 \pm 0.01$ & $439 \pm 11$ & 12 & $3.9 \pm 0.1$ & $112 \pm 5$ & $\geq 169 \pm 9$ \\
\hline $062206 \mathrm{Kf}$ & $\begin{array}{l}\text { Atalaia } \\
\text { (sport ground) }\end{array}$ & IV & 57 & T4 top & Medium sand & $0.92 \pm 0.01$ & $289 \pm 4$ & 12 & $2.5 \pm 0.1$ & $115 \pm 5$ & $\geq 172 \pm 6$ \\
\hline $052240 \mathrm{Kf}$ & Entroncamento & IV & 30 & T5 top & Silt & $0.96 \pm 0.00$ & $309 \pm 7$ & 12 & $4.6 \pm 0.2$ & $68 \pm 3$ & $99 \pm 6$ \\
\hline $072230 \mathrm{Kf}$ & P.da Pedra- 0801 & IV & 40 & T4 base & Very fine sand & - & $377 \pm 40$ & 6 & $3.4 \pm 0.1$ & $110 \pm 12$ & $\geq 175 \pm 6$ \\
\hline $072231 \mathrm{Qz}$ & P.da Pedra-0803 & IV & 36 & T6 Top & Medium sand & - & $\mathbf{9 9} \pm \mathbf{2}$ & 6 & $4.3 \pm 0.1$ & $29 \pm 2$ & - \\
\hline $072229 \mathrm{Kf}$ & Golegã1 & IV & 21.7 & T6 middle & Medium sand & - & $282 \pm 5$ & 6 & $6.3 \pm 0.2$ & $45 \pm 2$ & $56 \pm 2$ \\
\hline $062207 \mathrm{Kf}$ & Courelas & IV & 25 & T6 top & Fine sand & $1.01 \pm 0.01$ & $163 \pm 5$ & 11 & $4.7 \pm 0.2$ & $35 \pm 2$ & $51 \pm 3$ \\
\hline
\end{tabular}

of the lithic assemblages, and to place the archaeological sites within the context of the Quaternary deposits of the Tejo River and its tributaries (Oosterbeek et al., 2004). To achieve these goals, a series of surface lithic collections, excavations of both Pleistocene and Holocene sites and production of thematic maps were made in order to provide a more detailed understanding of the archaeological sites and their geological context (Corral, 1998a,b).

From a geomorphological and lithostratigraphic perspective, the identification of the fluvial terraces in the Lower Tejo valley has also been improved. Following a geomorphological study by Costa (1984), the 'low terrace' was locally subdivided into terraces Q4-a and Q4-b (Zbyszewski and Carvalhosa, 1984; Rosina, 2002), Q4-1 and Q4-2 (Corral, 1998a), T5 and T5a (Martins, 1999). Martins (1999) also identified and characterized an oldest terrace (T1), located above the Q1 of the nomenclature proposed by Zbyszewski. In the Nabão River six terraces were mapped and their sedimentary deposits characterized (Mozzi, 1998; Reis, 1998; Mozzi et al., 1999). However, these independent studies created a profusion of names and distinct age proposals, which are very difficult to correlate with the terrace remnants along the Tejo valley, especially where some units are missing or where they have been vertically displaced by faults (Costa, 1984; Daveau, 1993; Cabral, 1995; Martins, 1999; Cunha et al., 2005).

Cunha et al. (2008) identified five terraces in the Ródão area but also noted that terrace $\mathrm{T} 2$ is a complex terrace that consists of two distinct surfaces (at $155 \mathrm{~m}$ a.s.l. and $133 \mathrm{~m}$ a.s.l., respectively); their study presented several luminescence ages from the three lower terraces (ranging from $\sim 280$ to $32 \mathrm{ka}$ ) and summarized the lithic industries associated with them. As a result, using the terrace codes that are now applied at the scale of the Lower Tejo basin, the terraces identified at the Ródão-Monte do Pinhal area should be designated as follows: $\mathrm{T} 1+117 \mathrm{~m}$ a.r.b. (183 $\mathrm{m}$ a.s.l.); T2 +89 $\mathrm{m}$ a.r.b. (155 $\mathrm{m}$ a.s.l.); T3 +67 $\mathrm{m}$ a.r.b. (133 $\mathrm{m}$ a.s.l.); $\mathrm{T} 4+50 \mathrm{~m}$ a.r.b. (116 $\mathrm{m}$ a.s.l.); $\mathrm{T} 5+24 \mathrm{~m}$ a.r.b. (90 $\mathrm{m}$ a.s.l.); T6 +16 $\mathrm{m}$ a.r.b. (82 $\mathrm{m}$ a.s.l.).

Further downstream, between Gavião and Chamusca, six terraces were identified in total, because of the subdivision of T4 into two steps, T4a and T4b (Martins et al., 2009a). The significant number of OSL ages obtained in those two studies supported the longitudinal correlation of the terraces among several sectors of the Tejo River, despite the existence of active faults (mainly NNE-SSW and WNW-ESE systems).

\section{Materials and methods}

Detailed geomorphological and lithostratigraphic mapping were involved in the present study, as well as characterization of the depositional architecture of the terraces and sedimentary deposits associated with the archaeological sites. The archaeological methods used an approach that combined extensive surface surveys, excavation of sedimentary deposits, and characterization and interpretation of artefacts. Finally, optically stimulated luminescence (OSL) was the technique chosen for sediment dating.

Four new samples (Table 1), in addition to those already published for this region (Cunha et al., 2008; Martins et al., 2009a), were dated using $\mathrm{K}$-feldspar (Kf) infrared stimulated luminescence (IRSL). Sand-sized $(180-250 \mu \mathrm{m}) \mathrm{Kf}$ grains were extracted using conventional luminescence sample preparation techniques (sieving, $\mathrm{HCl}, \mathrm{H}_{2} \mathrm{O}_{2}$, density separation at $2.58 \mathrm{~g} /$ $\mathrm{cm}^{3}$ ). The Kf grains were etched in diluted HF (10\%) for $40 \mathrm{~min}$ to remove surface coatings and any contribution from external alpha radiation. Luminescence measurements were performed on a Risø TL/OSL DA-15 reader, with luminescence detection through a standard blue filter combination (Schott BG39 and Corning 7-59; Bøtter-Jensen et al., 2003). Small (2 mm) aliquots were mounted with silicone spray on stainless steel cups. The SAR (Murray and Wintle, 2000) procedure was used to measure the $D_{\mathrm{e}}$ and $g$ values, using the same thermal treatment prior to measurement of the IRSL natural/regenerated and of the IRSL test dose signals $\left(250{ }^{\circ} \mathrm{C}\right.$ for $60 \mathrm{~s}$; Auclair et al., 2003; Huot and Lamothe, 2003). An elevated temperature IRSL cleanout (at $290{ }^{\circ} \mathrm{C}$ for $40 \mathrm{~s}$ ) was used after every SAR cycle to reduce recuperation (Buylaert et al., 2007; Wallinga et al., 2007). Optical stimulation was carried out with infrared diodes $(875 \mathrm{~nm})$ for $100 \mathrm{~s}$ at $50{ }^{\circ} \mathrm{C}$. The initial $3.9 \mathrm{~s}$ of stimulation minus a background estimated from the last $9.2 \mathrm{~s}$ was used for all calculations. Radionuclide concentrations were measured using high-resolution gamma spectrometry of representative sub-samples (each 200-250 g; the gamma spectrometry calibration is described in Murray et al., 1987). The internal dose rates from ${ }^{40} \mathrm{~K}$ were based on an assumed $\mathrm{K}$ content of $12.0 \pm 0.5 \%$ (Huntley and Baril, 1997) and the internal contribution from $U$ and Th was taken as $0.10 \pm 0.05 \mathrm{~Gy} / \mathrm{ka}$. The total dose rates lie in the range $2.5-6.3 \mathrm{~Gy} / \mathrm{ka}$. The fading correction used the dose rate correction (DRC) model of Lamothe et al. (2003) to calculate fading-corrected ages.

\section{Terrace staircases}

From the culminant sedimentary surface (CSS, 200-240 m a.s.l.) down to the modern river bed, drainage evolution has created a staircase of six terraces (and coeval erosive surfaces; Table 2), a narrow valley cut into the basement and a modern alluvial plain. Transverse profiles (Figs. 5-7) illustrate some of these geomorphological units.

The CSS corresponds with the top of the Cenozoic infill of the Lower Tejo basin. This surface was strongly dissected by the Tejo and Zêzere fluvial systems, and is only preserved on the top of small plateaus (Chorafome, $205 \mathrm{~m}$, and Medroa, $280 \mathrm{~m}$ ) to the west and east of the Zêzere River (Fig. 4). A localized basement high- 
Table 2

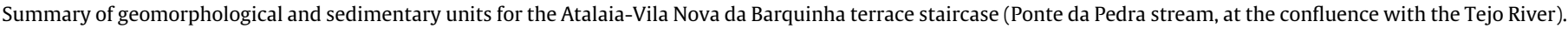

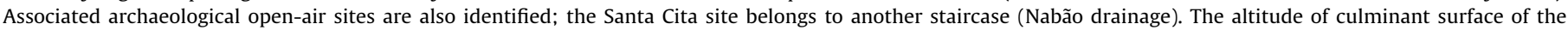

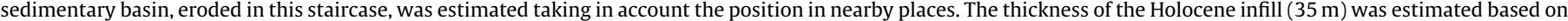
nearby wells made in the alluvial plain. Legend: a.s.l. - elevation above sea-level; a.a.p. - elevation above modern alluvial plain.

\begin{tabular}{|c|c|c|c|c|c|c|}
\hline $\begin{array}{l}\text { Geomorphologic } \\
\text { unit, main site }\end{array}$ & $\begin{array}{l}\text { Previous } \\
\text { down-cutting (m) }\end{array}$ & $\begin{array}{l}\text { Thickness } \\
(\mathrm{m})\end{array}$ & $\begin{array}{l}\text { Elevation } \\
\text { a.s.l. (a.a.p.) m }\end{array}$ & $\begin{array}{l}\text { Sedimentary characteristics } \\
\text { of the associated deposits }\end{array}$ & $\begin{array}{l}\text { Lithic industries } \\
\text { in stratigraphy }\end{array}$ & $\begin{array}{l}\text { Main archaeological } \\
\text { sites }\end{array}$ \\
\hline $\begin{array}{l}\text { Culminant surface } \\
\text { of the sedimentary } \\
\text { basin (eroded in } \\
\text { this straircase) }\end{array}$ & 0 & 29 & $180(+162)$ & $\begin{array}{l}\text { Reddish very coarse sands with } \\
\text { through cross lamination and } \\
\text { gravels of quartzite }(33 \%) \text { and } \\
\text { quartz }(67 \%) \text { clasts (MPS }=15 \mathrm{~cm} \text { ) }\end{array}$ & Not found & Absent \\
\hline Terrace T1, Barquinha & $(180-128) 52$ & 14 & $142(+124)$ & $\begin{array}{l}\text { Reddish gravely coarse sands; } \\
\text { larger clasts are mainly of quartz } \\
(\mathrm{MPS}=12 \mathrm{~cm})\end{array}$ & Not found & Absent \\
\hline $\begin{array}{r}\text { Terrace T2, Chão } \\
\text { dos Eucaliptos }\end{array}$ & $(142-92) 50$ & 18 & $110(+92)$ & $\begin{array}{l}\text { Reddish massive clast-supported } \\
\text { gravels of quartzite }(65 \%) \text { and } \\
\text { quartz }(35 \%) \text { clasts }(\mathrm{MPS}=22 \mathrm{~cm})\end{array}$ & Not found & Absent \\
\hline $\begin{array}{l}\text { Terrace T3, Moita } \\
\text { football field }\end{array}$ & $(110-65) 45$ & 10 & $75(+57)$ & $\begin{array}{l}\text { Reddish massive clast-supported } \\
\text { gravels of quartzite }(65 \%) \text { and } \\
\text { quartz }(35 \%) \text { clasts, with sand } \\
\text { layers }(\mathrm{MPS}=21 \mathrm{~cm})\end{array}$ & Not found & Absent \\
\hline Terrace T4, Atalaia & $(75-43) 32$ & 12 & $55(+37)$ & $\begin{array}{l}\text { Matrix-supported gravel } \\
\text { predominates at the base but } \\
\text { coarse sands and silts at the } \\
\text { top (MPS }=25 \mathrm{~cm} \text { ); reddish colour }\end{array}$ & $\begin{array}{l}\text { Late Lower } \\
\text { Palaeolithic?/ } \\
\text { Languedocian; } \\
\text { occurrence } \\
\text { of Levallois debitage }\end{array}$ & $\begin{array}{l}\text { Fonte da Moita } \\
\text { (T4 base); Rib. } \\
\text { Ponte Pedra } \\
\text { (T4 base) }\end{array}$ \\
\hline $\begin{array}{l}\text { Terrace T5, } \\
\text { Entroncamento }\end{array}$ & $(55-24) 31$ & 10 & $34(+16)$ & $\begin{array}{l}\text { Massive or with through sets, } \\
\text { clast-supported gravels at the base, } \\
\text { followed by gravelly coarse } \\
\text { sands and upper silts (MPS }=25 \mathrm{~cm} \text { ); } \\
\text { reddish colour }\end{array}$ & $\begin{array}{l}\text { Middle Paleolithic? } \\
\text { (only a few artefacts } \\
\text { were collected) }\end{array}$ & $\begin{array}{l}\text { Rib. Ponte da } \\
\text { Pedra (T5 top) }\end{array}$ \\
\hline Terrace T6, Golegã & $(34-18) 16$ & 7 & $25(+7)$ & $\begin{array}{l}\text { Coarse to fine sands dominate; } \\
\text { some gravels at the base and } \\
\text { silts at the top (MPS }=7 \mathrm{~cm}) \\
\text { yellow colour }\end{array}$ & $\begin{array}{l}\text { Late Middle Palaeolithic } \\
\text { (Mousterian) }\end{array}$ & $\begin{array}{l}\text { Santa Cita (fluvial), } \\
\text { Termos }\end{array}$ \\
\hline $\begin{array}{l}\text { Colluvial unit or an } \\
\text { aeolian sand unit } \\
\text { on the valley slopes }\end{array}$ & & $\sim 2$ & Variable & $\begin{array}{l}\text { Reddish heterometric gravels } \\
\text { with sandy matrix or yellow } \\
\text { well-sorted, medium to } \\
\text { fine-grained sand }\end{array}$ & $\begin{array}{l}\text { Upper Palaeolithic to } \\
\text { Epipalaeolithic } \\
\text { (Magdalenian) }\end{array}$ & $\begin{array}{l}\text { Rib. Ponte daPedra } \\
\text { (colluvium); Santa } \\
\text { Cita (aeolian sands) }\end{array}$ \\
\hline $\begin{array}{l}\text { Valley fill deposits } \\
\text { underlying the } \\
\text { present floodplain }\end{array}$ & 65 & $\sim 35$ & $18(+0)$ & $\begin{array}{l}\text { The upper part of the sequence } \\
\text { consists of very coarse to fine } \\
\text { sands and silts }\end{array}$ & (Not analysed here) & Several sites \\
\hline
\end{tabular}

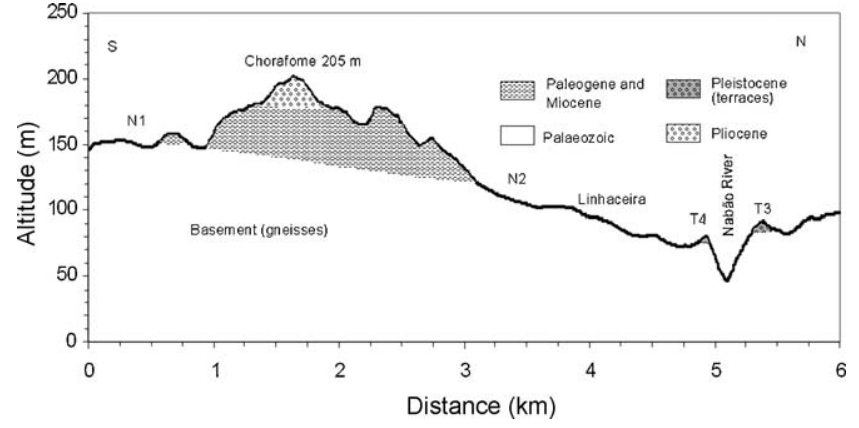

Fig. 5. Transverse profile from the Chorafome hill (205 m) to the Nabão River. Note the entrenched valley of the Nabão River after T3 formation.

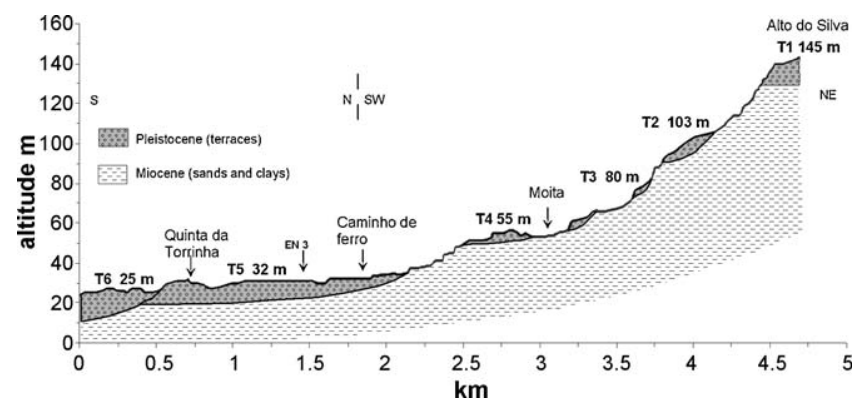

Fig. 6. Staircase of six fluvial terraces in the Vila Nova da Barquinha area. point (Martins, 1999) has vertically displaced the CSS by $30 \mathrm{~m}$ on the Medroa plateau ( $280 \mathrm{~m}$ a.s.l.) in comparison with the equivalent surface extending to the northeast.

Drainage incision down from the CSS to the modern entrenched valley probably started in the early Pleistocene. During this longterm incision, discontinuous down-cutting of the drainage promoted the development of six terraces ( $\mathrm{T} 1$ to $\mathrm{T} 6$ ) along the Tejo River and its main tributaries, the Zêzere and the Nabão (Figs. 4 and 6). The terraces are well developed within Entroncamento, Montalvo and Santa Cita depressions, where the staircases are complete or almost complete.

Below the CSS, an extensive erosion surface (N1) is connected to terrace T1 (Martins and Barbosa, 1992; Martins, 1999). The T1 terrace is well developed north of the Tejo and along the Zêzere

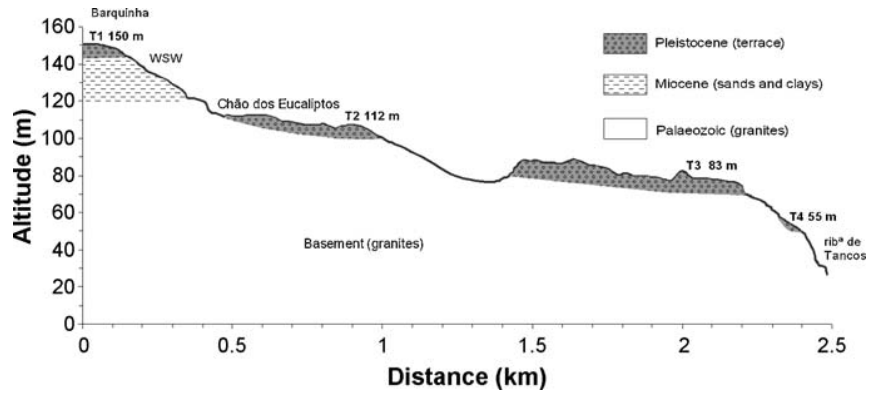

Fig. 7. Terrace staircase exposed in the cross-section of the Vila Nova da Barquinha plateau to Tancos stream. 


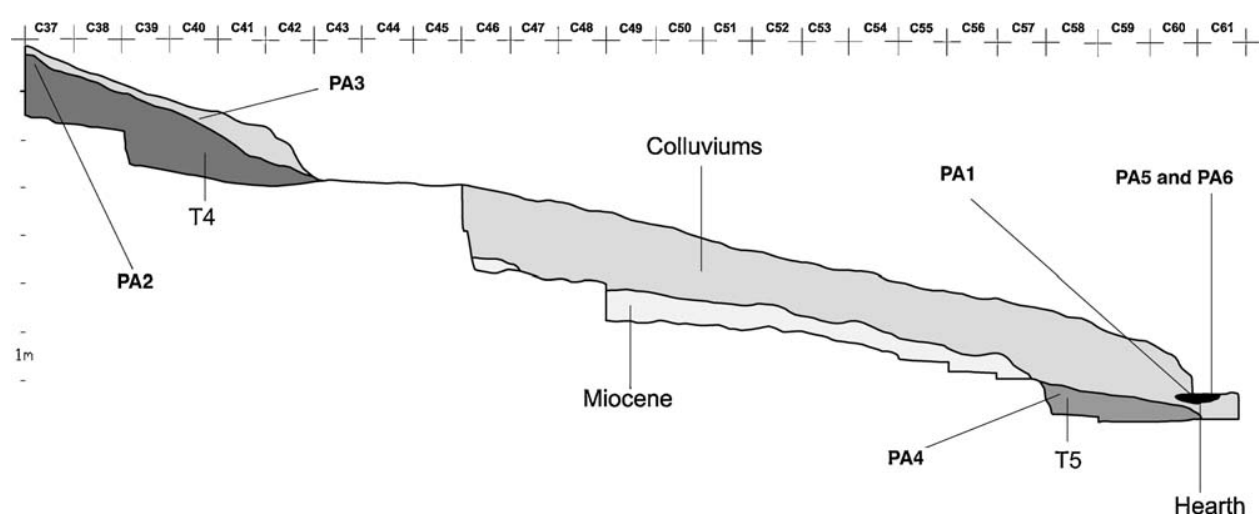

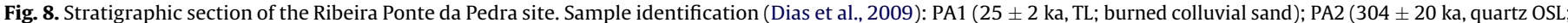

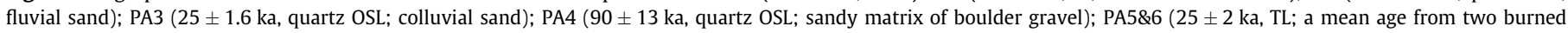

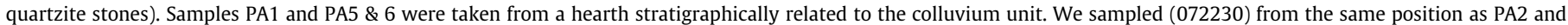
obtained a Kf IRSL age of $175 \pm 6 \mathrm{ka}$; in a nearby outcrop T6 provided a sample (072231) dated by quartz OSL as $29 \pm 2 \mathrm{ka}$.

valley at altitudes ranging from $170 \mathrm{~m}$ at Martinchel to $140 \mathrm{~m}$ north of Constância. Remnants of this terrace form flat-topped "buttes", at ca. $120 \mathrm{~m}$ above the modern river bed, standing out as a result of the deep incision by the Zêzere. Along this valley, T1 has a maximum thickness of $8 \mathrm{~m}$, and is made up of gravels and boulders overlying the metamorphic basement. The T1 deposits contains quartzite boulders of $34 \mathrm{~cm}$ MPS (MPS = maximum particle size: average dimension of the ten largest clasts in a stratigraphic level); $67 \%$ are quartzite and the remainder quartz. West of the Ponte da Pedra stream, on the small hill called Telégrafo $(119 \mathrm{~m})$, the T1 terrace (7-8 m thick) overlies Miocene sediments, but the MPS is only $12 \mathrm{~cm}$.

At Martinchel, the T1 surface is tilted $1.2 \%$ to the southwest (Martins, 1999). Tectonic displacement of T1 can also be deduced from the differences in altitude between the plateaus of Arripiado (135 $\mathrm{m}$ a.s.l., south of the Tejo) and Barquinha (150 $\mathrm{m}$ a.s.l., on the opposite side of the river). The Barquinha plateau is tilted to the northwest, reaching $139 \mathrm{~m}$ a.s.l. on its northwestern edge. Both the Barquinha and Arripiado plateaus, and the widespread flat-topped residual landforms at $140 \mathrm{~m}$ (between Atalaia and Santa Cita) are inversions of relief; they were ancient alluvial plains but now form "mesas" in the landscape. The geomorphic position of terrace T1, above the present water divide of the Nabão and Tejo drainage basins, led Mozzi (1998) to consider an earlier north-south connection between the Nabão and the Tejo, before the capture of the former by the Zêzere River in the Santa Cita area. We agree with this ancestral course of the Nabão River; fluvial terraces are unusual in headwaters, where the discharges are not enough to enlarge valleys and there is usually not enough time to promote lateral erosion (Leopold et al., 1964). The T1 and T2 terraces, in the Santa Cita-Atalaia corridor, are presumed to belong to the ancestral Nabão rather than the Zêzere, because the latter flowed towards the south in the Martinchel-Constância corridor, as is testified by remains of terrace $\mathrm{T} 1$ in that $\mathrm{N}-\mathrm{S}$ route.

Terrace $\mathrm{T} 2$ is well represented by small steps at $110-112 \mathrm{~m}$ along the Tejo River, but increases to ca. $128 \mathrm{~m}$ along the Zêzere valley. At Chão dos Eucaliptos (Fig. 7) the deposits forming this terrace are ca. $12 \mathrm{~m}$ thick, mainly composed of massive reddish clast-supported quartzite (65\%) and quartz (35\%) gravels (MPS = 22 cm).

Terrace T3 is well developed in the Montalvo, Tancos airport and Entroncamento depressions. Its altitude decreases from $83 \mathrm{~m}$ at Montalvo, to $70 \mathrm{~m}$ at Vila Nova da Barquinha $(12 \mathrm{~km}$ downstream) and $60 \mathrm{~m}$ west of Entroncamento. Several outcrops along the Constância-Tancos road expose this terrace, which is mainly composed of massive clast-supported gravels comprising quartzite and quartz clasts (in similar proportions as in the terrace T2 gravels). The MPS is $21 \mathrm{~cm}$.
The T4 surface has an altitude of ca. $55 \mathrm{~m}$ at Montalvo and $45 \mathrm{~m}$ in the Entroncamento area. It is made up of a massive basal clastsupported gravelly unit, 2-3 m thick, passing upwards to gravels interbedded with sand layers.

Near the village of Atalaia (Fig. 4) T4 has a thickness of $\sim 11 \mathrm{~m}$, with its surface at $55 \mathrm{~m}$ a.s.l. At the Atalaia sports-ground is exposed, from bottom to top, $0.5 \mathrm{~m}$ of reddish matrix-supported gravel, $0.6 \mathrm{~m}$ of fine sand, grading upwards to a red silt ( $0.2 \mathrm{~m}$ thick), $0.7 \mathrm{~m}$ of reddish clast-supported gravel (MPS $=2 \mathrm{~cm}$ ) rich in angular white quartz and containing artefacts and, finally, $0.2 \mathrm{~m}$ of sandy soil, also containing artefacts (Grimaldi et al., 1999a). At Ribeira Ponte da Pedra, T4 (with its base at $34 \mathrm{~m}$ a.s.l.) consists (from bottom to top) of $4 \mathrm{~m}$ of reddish boulder gravel (MPS $=25 \mathrm{~cm}$ ) with a silty-sand matrix rich in lithic artefacts, a $0.3 \mathrm{~m}$ thick layer of orange coarse to very coarse pebbly sand, $0.2 \mathrm{~m}$ of gravel and $0.3 \mathrm{~m}$ of very fine sand to silt, capped by $<0.5 \mathrm{~m}$ of gravel.

At the Fonte da Moita, near Vila Nova da Barquinha, the basal layer of T4 is $1.5 \mathrm{~m}$ thick and consists of gravels (MPS = $30 \mathrm{~cm}$ ) with a coarse sandy matrix, and medium sands towards the top. The upper layer, $80 \mathrm{~cm}$ thick, begins with an erosive contact and comprises sandy gravel (MPS $=15 \mathrm{~cm}$ ) with a coarse sandy matrix and some thin silt layers (Grimaldi et al., 1999b, 2000).

$\mathrm{T} 5$ and $\mathrm{T} 6$ (the two lower terraces) are only represented within the depressions of Santa Cita, Montalvo and Entroncamento. In the Entroncamento depression T5 and T6 are difficult to distinguish on geomorphological grounds (Fig. 4). However, at the village of Azinhaga (Fig. 2) they are found at different levels: T5 at $24 \mathrm{~m}$ and T6 at $18 \mathrm{~m}$ (a.s.l.).

At Ribeira da Ponte da Pedra and Fonte da Moita, where detailed observations were made and reported by Oosterbeek et al. (2004), a trench shows a Miocene substratum covered by deposits of T4, T5 and an upper colluvium (Fig. 8). T5 has a surface at $32 \mathrm{~m}$ a.s.l. and consists of clast-supported gravels (MPS $=15 \mathrm{~cm}$ ). As with T4 in the same area, the terrace is covered by a diamict colluvium, with a sandy matrix and reddish brown (near surface) colour. Recently, a sedimentary sequence (surface at $\sim 32 \mathrm{~m}$ a.s.l.), $>2 \mathrm{~m}$ thick and consisting of basal gravely coarse sands and an upper sandy silt, was identified as representing the T6 terrace.

Along the Nabão River, T6 overlies Miocene silty-clays and comprises the following sequence (Lussu et al., 2001):

Unit B1 (0.4 m thick) - yellow sandy clays, containing, at their erosive base, a second level ( $0.1 \mathrm{~m}$ thick).

Unit B2 (0.6 m thick) - reddish sands to silty-clays.

Unit C1 (1.5 m thick) - lower gravels with a silty-sand matrix (quartzite and quartz cobbles), MPS $=10 \mathrm{~cm}$, interbeded with coarse to medium sands. 
Terrace T6 is covered by an upper layer of aeolian silts and very fine sands (Unit A; ca. $0.5 \mathrm{~m}$ thick).

\section{Archaeological sites and lithic industries}

In the Atalaia-Ribeira da Ponte da Pedra area, in situ lithic industries, mainly employing local quartzite pebbles, were found in T4, T5 and in colluvium (Corral, 1998a,b; Grimaldi et al., 1998, 1999a,b; Grimaldi and Rosina, 2001).

\subsection{Ribeira da Ponte da Pedra site}

The excavation of the Ribeira da Ponte da Pedra archaeological site (Fig. 3) dating back to 1999, is the only one still going on; the other excavations in fluvial terraces, at the Fonte da Moita and Santa Cita sites, are abandoned. At the Ribeira da Ponte da Pedra site, 3300 lithic implements have been collected at the base of T4, on the surface of $\mathrm{T} 5$ and in the upper colluvium unit.

The lithic industry found at the base of T4 ( 1500 artefacts) is essentially characterized by three major groups: (a) worked pebbles, (b) non retouched blanks and (c) apparently retouched blanks. These groups can be viewed as the result of a simple technological reduction sequence: pebbles have been knapped in order to produce mainly cortical and half-cortical flakes. The reduced number of flake scares can be associated with 'expedient' production of large/ massive blanks and may also indicate a functional necessity based on quantity, rather than quality, of the blanks. Nevertheless, some of these worked pebbles present features that indicate their utilization as chopping tools (Cristiani et al., in press). Apparently retouched blanks are mainly cortical or semi-cortical. The implements analysed so far present a marginal, coarse and atypical retouch, which does not result in classic types of tools. This behaviour can be explained by the fact that blanks could have been made to provide functional cutting or scraping edges, without needing to be retouched; the atypical retouch is thus a consequence of use. Ongoing experimental and functional studies strongly support this hypothesis. At this stage in our research we can conclude that most of the edges showing an 'atypical' retouch can be attributed to different types of edge modifications resulting from subsistence activities, mainly related to wood work (Cristiani et al., in press).

The scanty lithic assemblage found at the top of T5 show technological features similar to those of the base of T4. Nevertheless, several differences are noted; for instance, the number of cores is higher than in T4. We also identify bifacial tools, the presence of discoid and Levallois products, as well as some regularly retouched implements.

In the colluvium deposits ca. 2000 lithic implements were collected; here we underline the presence of a sub-circular (ca. $90 \mathrm{~cm} \times 150 \mathrm{~cm}$ ) hearth at the base of these deposits, just above the top of the underlying T5. Burnt stones and burnt sediments define the structure; the stones are local quartzite pebbles with clear signs of rubefaction. The hearth shows burnt grey sediments, a few centimetres thick, covered by thermoclastic horizontally layered pebbles. No lithic artefacts have been found in association with the fire structure.

The artefacts found in the colluvium are made mainly from local raw materials without any clear typological markers. This specific context raises the question of how far the rarity of Upper Palaeolithic open-air sites in the Portuguese Tejo valley is due to their absence rather than to the difficulty of recognizing characteristic features.

\subsection{Atalaia sports-ground}

The top of T4 provided a few implements that seem to have morphologically and technologically different features (Grimaldi et al., 1999a). Some cores are typologically definable as Levallois and can be technologically included in discoid debitage. This site also provided in situ implements made from flint: a bi-planar core and a Levallois-like flake.

\subsection{Fonte da Moita}

At the Fonte da Moita site (near Vila Nova da Barquinha), an archaeological rescue excavation of a $50 \mathrm{~m}^{2}$ area reached a depth of $2.5 \mathrm{~m}$ and exposed the base of the T4 above the underlying Miocene at an altitude of $45 \mathrm{~m}$ (Grimaldi et al., 1999b, 2000). In the excavation a total of 2852 lithic implements were found, made mainly from different types of local quartzite pebbles and boulders, and attributed to the Lower Palaeolithic (Grimaldi et al., 1999b, 2000; Jaime, 2002). They are characterized by a great variability in the degree of patina, post-depositional fractures, and/ or chemical alterations; their cutting edges vary from very fresh angular to well rounded. As in Ribeira Ponte da Pedra, "classic morphological types" (according to Borde's list) are very rare. Functional analyses also indicate that some of these edge modifications could result from use in different subsistence tasks. Lemorini et al. (2001) suggested work on hard and very hard materials, mainly the scraping of (probably) wood and horn; dry hide was also scraped, and there is also evidence of meat and bone cutting and scraping, representing butchering activities.

\subsection{Santa Cita}

This archaeological site, discovered in 1990 and situated on Terrace T6, was excavated between 1991 and 2000 over an area of $70 \mathrm{~m}^{2}$ (Bicho and Ferring, 2001). Two archaeological levels were identified in the T6 deposits and $\sim 5000$ artefacts have been collected (Bicho and Ferring, 2001; Lussu et al., 2001). According to these authors, here in the lower unit of T6 (C1) were discovered flakes ascribed to the Palaeolithic, whereas in the base of Unit B2 and in the overlying unit B1, were found numerous artefacts $(\sim 100)$ ascribed to the Mousterian. The upper layer of aeolian silts and very fine sands (unit A) provided Epipalaeolithic artefacts and a burning structure at the base and probable Calcolithic materials at the top. The lithic implements found in Terrace T6 present some dissimilarities in their degree of edge preservation, but technologically and typologically they do not show significant differences. Local raw materials (quartzite and quartz) predominate. Although less often employed, flint played an important role in artefact manufacture, being exhaustively exploited, as is proved by both the technological features of cores and the numerous refittings identified.

The archaeological level located within the upper aeolian sands contained carinated scrapers, Dufour bladelets, microlithic implements, microburins and backed bladelets, suggesting a short Epipalaeolithic occupation.

This site does not have absolute ages and the present poor exposure conditions of the succession prevented luminescence sampling. However, the techno-typological characteristics of the lithic industries, pointing to late Mousterian, are compatible with its geomorphic position in T6.

\section{Luminescence dating}

Thus far the oldest artefacts have been found at the base of T4, respectively at the Fonte da Moita and Ribeira da Ponte da Pedra (Fig. 8) sites. Dias et al. (2009) have obtained several optically stimulated luminescence (OSL) ages based on quartz: $304 \pm 20 \mathrm{ka}$ (PA2) from a very fine sand bed, located $\sim 2 \mathrm{~m}$ above the base of T4; $90 \pm 13 \mathrm{ka}$ (PA4) from the sandy matrix of the T5 boulder gravel; $24.8 \pm 1.6 \mathrm{ka}$ from the colluvium sandy matrix (PA3). They also 
obtained age estimates from TL dating of a hearth discovered at the base of the colluvium, these being $25 \pm 2 \mathrm{ka}$ (PA1), from burned colluvial sands, and a mean of $24.9 \pm 2.2 \mathrm{ka}$ (PA5 and PA6) from two burned quartzite stones. The very fine sand layer interbeded in the basal T4 gravels is now dated to $\geq 175 \pm 16$ ka (Kf IRSL, including correction for anomalous fading); the significant discrepancy in age compared with the result obtained by Dias et al. (2009) requires further investigation.

At the Atalaia football field, the top of T4 has an age of $\geq 172 \pm 6 \mathrm{ka}$, and so this should be the minimum age of the artefacts collected there. The top of T4 at the Vila Nova da Barquinha chapel, very close to the Fonte da Moita site and in the same terrace, provided an age of $\geq 169 \pm 9 \mathrm{ka}$.

Measurements in four new samples (052236 - T3, 072229 - T6, 072230 - T4, 072231 - T6) were made using K-feldspar IRSL or quartz OSL (Table 1); the latter method was used when the quartz signals were not in saturation.

Luminescence ages, derived by dividing the equivalent doses $\left(D_{\mathrm{e}}\right)$ by the total dose rates, are summarized in Table 1 . Because of anomalous fading, Kf ages needed to be corrected. Cunha et al. (2008) and Martins et al. (2009a,b) have shown that the fadingcorrected feldspar ages are in good agreement with quartz OSL and U-series ages. However, we are sceptical of the accuracy of the age obtained from sample 052236, with an uncorrected $D_{\mathrm{e}}$ of $585 \pm 24 \mathrm{~Gy}$; in such cases the DRC model puts the natural signals close to luminescence saturation, giving a minimum corrected $D_{\mathrm{e}}$ of about $1000 \mathrm{~Gy}$ and so a minimum age.

Integration of the previous luminescence ages (Cunha et al., 2008; Martins et al., 2009a) with the four new ones allows us to propose the following age ranges for the late Pleistocene morphosedimentary units of the study area:

T3 is older than $300 \mathrm{ka}$.

T4 should be $\sim 300-160 \mathrm{ka}$.

T5 should be $\sim 136-75 \mathrm{ka}$.

T6 terrace should be $\sim 62-30 \mathrm{ka}$.

Colluvium unit an aeolian unit should be $\sim 26-14$ (?) ka.

This chronological framework may explain the fact that artefacts allocated to periods of river down-cutting (e.g. $\sim 150$ $130 \mathrm{ka}, \sim 70-62 \mathrm{ka}$ and $\sim 26-14$ (?) ka), have only been found in colluvium.

The Santa Cita archaeological site has been destroyed, and so it is not possible to obtain luminescence ages from the stratigraphic levels containing artefacts. However, the geomorphic position of the deposit ascribes it to T6, implying an age of $\sim 60-30$ ka for the Mousterian levels found in this site.

\section{Reconstruction of fluvial evolution and human occupation}

The terrace age controls show that the classic four glacialinterglacial climatic periods of the Alpine chronology are inadequate to provide a temporal framework for the Portuguese Tejo terraces. For example, the glacial 'Riss' period ( 380-125 ka) brackets the marine oxygen isotope stages (MIS) 9 and 7 (interglacial periods that have high sea-level) and MIS10, 8 and 6 (periods of cold climate and low sea-level) (Shackleton et al., 1990; Wright, 2000).

The new dating results (samples 062204, 062206, 062208 and 07230) also have implications for the controversial age of the classic 'Q3 - middle terrace', now designated as T4 and identified along the Lower Tejo basin (Table 3 ). It is inappropriate to ascribe it to the Mindel/Riss (Holsteinian) interglacial or to the interglacial Riss - Würm (Eemian). The long period of aggradation of T4 (ca. 340-150 ka; Cunha et al., 2008; Martins et al., 2009a,b), which roughly corresponds with MIS9-6. The T5 deposits record the high sea-level of MIS5 and the T6 deposits that of MIS3.

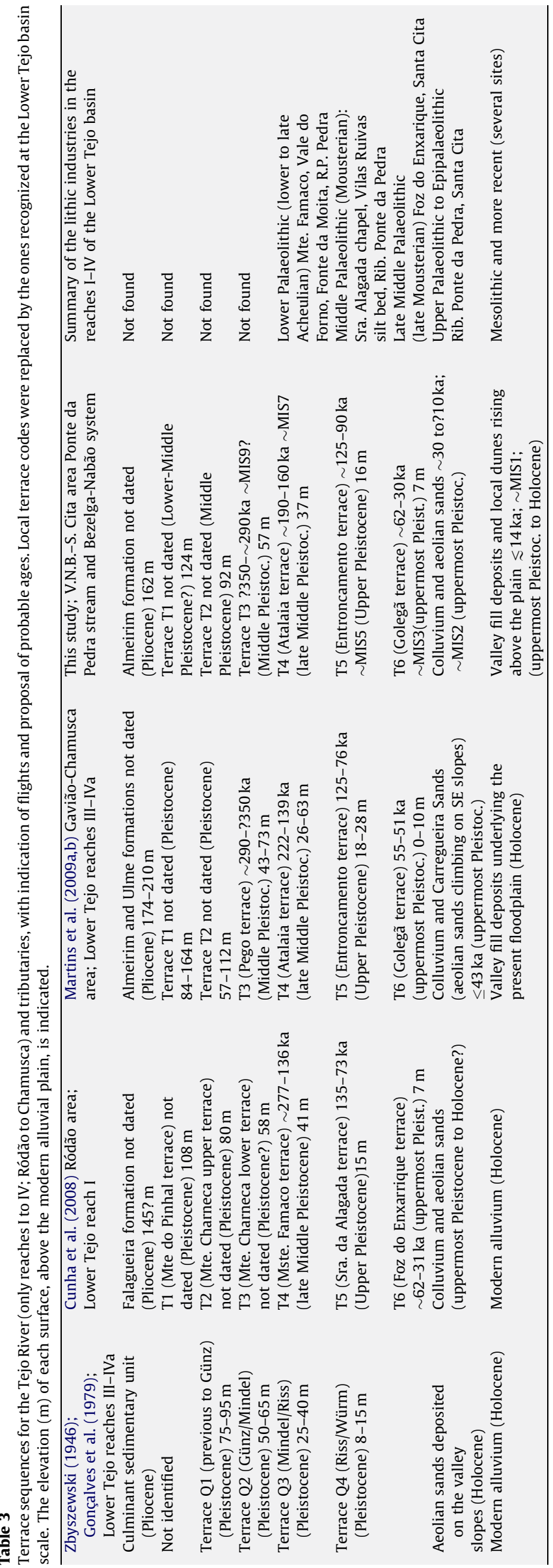


During the Middle and Late Pleistocene, the Lower Tejo basin seems to have been particularly sensitive to glacio-eustatism. The ongoing luminescence dating of the three lower terraces supports the interpretation that their formation was due to alternating climatic/eustatic conditions related to Pleistocene glacial-interglacial cycles. Dating indicates that the periods of river down-cutting (incision events) coincide with low sea-level periods and cooler climate conditions. Down-cutting would be facilitated by the Portuguese narrow continental shelf and the proximity of the Cascais and Lisboa canyons, to the SW of the mouth of the Tejo. The study by Vis et al. (2008) and Vis (2009) shows that the pronounced incision by the Tejo during the Late Pleistocene, up to $\sim 100 \mathrm{~km}$ upstream from the present coastline, occurred during the last glacial sea-level lowstand, contrary to the proposal of Van der Schriek et al. (2007) that major aggradation episodes were probably related to cold phases and that fluvial incision took place during climate transitions. Evidence from the oceans has revealed the great complexity of Quaternary climate variation, but the interpretation of the consequences of these changes for deposition and terrace formation in the Lower Tejo basin and nearby basins have been limited previously by the sparse available age data set. Many terrace sequences can now be reliably dated and correlated with MIS, allowing potentially useful patterns in artefact distribution to be recognized (Bridgland et al., 2006).

The terrace deposits constitute a record that can also provide information on climate and environment. For example, the T1 to T4 deposits show typical reddening, high clay content and swell-andshrink structures of clayey soils that point to conditions of mildtemperate climate, with alternating rainy and dry seasons. T6 and the associated upper aeolian sands have a yellow to white colour and vestigial clay content, suggesting much colder conditions during deposition. Because during Pleistocene times this region had no glaciers, we can envisage continuous human occupation. However, it is likely that the hunter-gatherer groups adapted to the environmental modifications caused by sea-level and climatic changes (migration in order to follow the most favourable environments and resources). During glacial maxima, fauna and humans would have retreated southwest towards southern France and Iberia, returning north when conditions were less hostile (Bridgland et al., 2006).

In the Portuguese Tejo reaches I to IV, the prehistoric archaeological record is almost completely limited to lithic artefacts: (a) the Monte do Famaco site (Rodão; Fig. 1; Raposo, 1987), with lower to middle Acheulian (lower Palaeolithic) industries found in situ in T4 and in an associated colluvium, and a probable late Acheulian (Middle Palaeolithic) industry on the surface; (b) Vale do Forno (Alpiarça; Fig. 1; Raposo, 1995b, 2002), with middle Acheulian (Lower Palaeolithic) to late Acheulian (Micoquian) industries (early Middle Palaeolithic) collected from middle part of T4; (c) the Ribeira da Ponte da Pedra and Fonte da Moita industries, collected at the base of T4. These last two assemblages are characterized by the production of cutting edges, obtained with simple debitage reduction sequences. Nevertheless, the blanks produced and used at these sites are morphologically and metrically standardized, and the frequency of bifaces at these sites is quite small (Oosterbeek et al., in press): Monte do Famaco 34 artefacts ( 4 bifaces); Ribeira da Ponte da Pedra -815 artefacts ( 0 bifaces); Fonte da Moita - 2852 artefacts ( 1 biface); Vale do Forno 338 artefacts (24 bifaces). The known underestimation of the Kf corrected ages (Cunha et al., 2008; Martins et al., 2009a,b) suggests that T4 could be $\sim 340-150 \mathrm{ka}$ ( $\sim$ MIS9-6). We should also note that in the Lower Tejo basin, the oldest in situ industries were found at the base of T4.

Small tools could be a response to poor-quality raw material (Bridgland et al., 2006). It could be argued that the Tejo sediments, containing abundant well-rolled quartzite boulders, were more suitable for the characteristic Acheulian large cutting tools than the sediments of the Tejo tributaries (e.g. Ponte da Pedra stream), even if this different availability cannot be interpreted as a main conditioning factor of the excavated assemblages, given the short distance between both.

Therefore, instead of placing the interpretation within a morpho-typological paradigm, it would be better to try a behavioural one. Indeed, we should leave aside a strictly typological identification and try to have an approach more focused on the manufacture process and possible concurrent behaviour patterns and strategies. That is, we should study the correlation between each context and its internal variability and the different geoarchaeological features. This is the most appropriate way to associate different sites along the Tejo valley and to achieve a better delineation of human settlement and land use during the Pleistocene.

In the Vila Nova da Barquinha-Santa Cita area, the Palaeolithic industries provided by $\mathrm{T} 4$ and $\mathrm{T} 5$ could be part of varied subsistence behaviour in keeping with local resources. Such a hypothesis is strengthened by the complete reduction sequences found at the site (Grimaldi et al., 1998, 1999a,b; Cura and Grimaldi, 2009), and by results of experimental and functional studies; these indicate actions related with wood working and supply, horn, fresh and dry hide preparation and butchering activities (Lemorini et al., 2001; Cristiani et al., in press). Such variability has to be set together with the other late Middle Pleistocene T4 sites in the Tejo valley (e.g. Monte do Famaco and Vale do Forno) through a comparison of the lithic assemblages and geoarchaeological contexts.

Data integration also allows some further interpretation concerning human occupation of the landscape. Because in the Atalaia area the artefacts were collected from the base to the top of T4, we can suppose that about 200-170 ka ago hunter-gatherer groups used this area of active sedimentation on the banks of a gravely braided river (the ancestral Atalaia stream). At the terrace base the artefacts are more abundant, probably because the gravels were more suitable for exploitation. The in situ artefacts were found included in gravelly or sandy channelized fluvial sediments and their deposition presumably took place just after manufacture and use, respectively. In the gravelly contexts, the dominance of artefacts with sharp edge points does not leave room for significant transport (after use) during medium to high river discharges.

Terrace T5 consists of the coarse gravelly channel deposits of a braided stream; the artefacts are insufficiently abundant to allow an accurate characterization of the industry but do indicate that they were produced locally. According to the luminescence ages, the T5 deposits record the temperate conditions of MIS5.

At Santa Cita, the gravely channel deposits at the base of $\mathrm{T} 6$ contains rare flakes. The occupation levels corresponding to the Mousterian industries in the upper gravels and sands overlain by two floodplain fluvial clay layers points to a temporary settlement and subsequent abandonment of the local human (supposedly Neanderthal) occupation caused by increasingly flooded conditions. The T6 deposits ( $\sim 62-30 \mathrm{ka})$ probably record the cold but humid conditions of MIS3. The continuation of Mousterian industries (both in caves and open-air sites) until $\sim 28-27 \mathrm{ka}$ is well testified in Portugal, and the termination is coeval with the extinction of both Neanderthals and megafauna (Raposo, 2000, 2002).

The hearth and artefacts found associated with the colluvium dated as $25 \mathrm{ka}$ at Ribeira da Ponte da Pedra, and the Epipalaeolithic artefacts and combustion structure found in the aeolian sands and silts of Santa Cita, are important to the interpretation of the human behaviour in the region. In central Portugal, there is abundant 
evidence of human occupation in caves during the Upper Palaeolithic (Roche, 1971; Zilhão, 1997a,b; Bicho, 2000; Corchón and Cardoso, 2005; Aubry and Bicho, 2006; Aubry et al., 2008), a period characterized by cold and dry conditions between 31 and $23 \mathrm{ka}$ (Roucoux et al., 2005). Evidence of such occupation is rare on the Tejo valley slopes, presumably because Holocene alluvium buried any artefacts located along the river valley.

\section{Conclusions}

In earlier work by Cunha et al. (2008) and Martins et al. (2009a,b), detailed geomorphological mapping, coupled with lithostratigraphy, sedimentology and luminescence dating, supported the correlation of Lower Tejo River terraces between distinct areas. It also allowed the identification of the complete regional terrace staircase, now shown to be made up of six terraces located below the culminant sedimentary unit; this represent the ancestral fluvial systems during the Pliocene, before the incision stage. In their studies, both quartz OSL and potassium-feldspar IRSL were used to date sediment samples of the T6 and the younger aeolian units, but only potassium-feldspar IRSL (with correction for anomalous fading) was used when quartz was in saturation, as in the $\mathrm{T} 5, \mathrm{~T} 4$ and $\mathrm{T} 3$ terraces.

Luminescence dating from this and earlier studies provides ages for the deposits of the lower terraces of the Portuguese Tejo basin: T3 is older than $300 \mathrm{ka}$, probably $\sim 410-370 \mathrm{ka}$; T4 is probably $\sim 340-160 \mathrm{ka}$; T5 is $\sim 136-75 \mathrm{ka}$; and T6 is $\sim 62-30 \mathrm{ka}$. These new ages allows us both to discard the previously hypothesized chronology for T4 (formerly Q3) and also to produce a more consistent interpretation of sedimentary controls. Continuous uplift and cyclic climatic-eustatic fluctuation provided the trigger for the fluvial aggradation and incision events that led to the formation of terrace staircases in this basin.

Luminescence dating also provides ages for the Lower Palaeolithic industries found in situ: (1) Fonte da Moita, T4 base, $\geq 180 \mathrm{ka}$; (2) Ribeira da Ponte da Pedra, T4 base, $\geq 175 \mathrm{ka}$; (3) Atalaia sports-ground, T4 top, $\geq 170 \mathrm{ka}$. The Lower to Middle Palaeolithic industries occur in fluvial terraces (T4 and T5) associated with some Tejo tributaries, and so typically do not record long-distance transport by the Tejo River. This could explain why the available raw material is dominated by locally-sourced quartzites and some quartz, but also why the lithic assemblages collected from different stratigraphic levels are characterized by the predominance of opportunistic and simple technological choices. The Upper Palaeolithic industries found in situ are associated with colluvium or aeolian sands.

By integrating the stratigraphic positions of the various archaeological sites and the luminescence ages obtained for the Portuguese Tejo reaches I to IV, it is possible to propose that:

(a) The earliest artefacts in the terrace staircase are associated with the base of T4 (terrace surface at $\$ 50 \mathrm{~m}$ ) above river bed (a.r.b.) and ages $\sim 280$ ka in Ródão and $\sim 180$ ka in the Vila Nova da Barquinha area, although it must be borne in mind that these $\mathrm{Kf}$ ages may be underestimates.

(b) The transition between the Lower and early Middle Palaeolithic is probably recorded by $\mathrm{T} 4$, but is not yet documented; further excavation of the Ribeira da Ponte da Pedra site is important for the understanding of this transition.

Detailed characterization and dating of lithic industries within the long-term and thick fluvial sedimentary record at a significant number of sites located in the Lower Tejo basin is continuing. This research has turned out to be very important for the interpretation of both human occupation and environmental change in western Iberia during the Pleistocene.

\section{Acknowledgements}

This work was undertaken within the scope of projects $\mathrm{POCI} /$ CTE-GEX/58120/2004 and PTDC/HAH/71361/2006, approved by the Fundação para a Ciência e a Tecnologia and co-founded by the FEDER. The Vila Nova da Barquinha town hall helped with the logistics of the archaeological excavation. Research was supported by the Polytechnic Institute of Tomar, Archaeology Interpretation Centre of the Alto Ribatejo, Museum of Prehistoric Art in Mação, IMAR-CMA-Univ. Coimbra, Centro de Geofísica-Univ. Évora, Centro de Geociências-Univ. Coimbra ("Quaternary and Pre-History" research group) and both Aarhus University and Risø DTU (Denmark).

\section{References}

Aubry, T., Bicho, N.F., 2006. Le Paléolithique supérieur du Portugal. Le Paléolithique supérieur européen. Bilan quinquennal 2001-2006, vol. 115. ERAUL, pp. 135-145.

Aubry, T., Almeida, N., Dimuccio, L., Gameiro, C., Neves, M.-J., Klaric, L., 2008 Caractérisation et discontinuités des registres pédo-sédimentaires de l'occident péninsulaire entre 30.000 et 10.000 BP. In: Aubry, T., Almeida, F., Cristina Araújo, A., Tiffagom, M. (Eds.), BAR S1831 2008: Proceedings of the XV World Congress UISPP (Lisbon, 4-9 September 2006) 21 Space and Time: Which Diachronies, which Synchronies, Which Scales?/Typology vs. Technology Proceedings of the XV UISPP World Congress (Lisbon, 4-9 September 2006)/Actes du XV Congrès Mondial (Lisbonne, 4-9 September 2006), Vol. 21. Sessions C64 and $\mathrm{C} 65$ 9-21.

Auclair, M., Lamothe, M., Huot, S., 2003. Measurement of anomalous fading for feldspar IRSL using SAR. Radiation Measurements 37, 487-492.

Barbosa, B.P., 1995. Alostratigrafia e Litostratigrafia das unidades continentais da Bacia Terciária do Baixo Tejo. Relações com o eustatismo e a tectónica. PhD Thesis. Univ. Lisboa, 253.

Benito, G., Sopena, A., Sanchez-Moya, Y., Machado, M.J., Perez-Gonzalez, A., 2003. Palaeoflood record of the Tagus River (Central Spain) during the Late Pleistocene and Holocene. Quaternary Science Reviews 22, 1737-1756.

Bettencourt, A., Ramos, L., 2003. Estuários Portugueses. Instituto da Água. Ministério das Cidades, Ordenamento do Território e Ambiente. Direcção de Serviços de Planeamento, Lisboa, p. 326.

Bicho, N., 2000. Technological Change in the Final Upper Paleolithic of Rio Maior. Arkeos, vol. 8. CEIPHAR, p. 454

Bicho, N., Ferring, C., 2001. O sítio arqueológico de Santa Cita, Tomar: as intervenções arqueológicas de 1990 a 1997. In: Cruz, A.R., Oosterbeek, L. (Eds.), Arkeos 11, Territórios, Mobilidade e Povoamento no Alto Ribatejo II, Santa Cita e o Quaternário da Região. CEIPHAR, pp. 71-88.

Bøtter-Jensen, L., Andersen, C.E., Duller, G.A.T., Murray, A.S., 2003. Developments in radiation, stimulation and observation facilities in luminescence measurements. Radiation Measurements 37, 535-541.

Breuil, H., Zbyszewski, G., 1942. Contribution à l'étude des industries Paléolithiques du Portugal et de leurs rapports avec la géologie du Quaternaire. Les principaux gisements des deux rivers de l'ancien estuaire du Tage, XXIII. Comunicações Serviços Geológicos de Portugal, Lisboa, p. 369.

Breuil, H., Zbyszewski, G., 1945. Contribution à létude des industries Paléolithiques du Portugal et de leurs rapports avec la géologie du Quaternaire. Les principaux gisements des plages quaternaires du littoral d'Estremadura et des terrasses fluviales de la basse vallée du Tage, XXVI. Comunicações Serviços Geológicos de Portugal, Lisboa, p. 662.

Bridgland, D.R., Antoine, P., Limondin-Lozouet, N., Santisteban, J.I., Westaway, R., White, M.J., 2006. The Palaeolithic occupation of Europe as revealed by evidence from the rivers: data from IGCP 449. Journal of Quaternary Science 21, 437-455.

Bridgland, D.R., Westaway, R., 2007. Climatically controlled river terrace staircases: a worldwide Quaternary phenomenon. Geomorphology 98, 285-315.

Buylaert, J.P., Vandenberghe, D., Murray, A.S., Huot, S., De Corte, F., Van den Haute, P., 2007. Luminescence dating of old $(>70 \mathrm{ka}$ ) Chinese loess: a comparison of single-aliquot OSL and IRSL techniques. Quaternary Geochronology 2, 9-14.

Cabral, J., 1995. Neotectónica de Portugal continental. Memórias do Instituto Geológico e Mineiro Portugal 31, 265.

Carvalho, A.M., 1968. Contribuição para o conhecimento geológico da bacia terciária do Tejo. Memórias dos Serviços Geológicos de Portugal 15, 210.

Corchón, M., Cardoso, J., 2005. Reflexiones sobre el Solutrense portugués: a propósito de la indústria Paleolítico Superior de Correio-Mor (Loures): on the Upper Paleolithic industry of Correio-Mor (Loures). Zephyrus - Salamanca, vol. 58. Universidad de Salamanca de la Facultad de Filosofia y Letras, ISSN: 0514-7336, pp. 89-110.

Corral, I. 1998a. Depositos Cuaternarios en el área de Constância-BarquinhaEntroncamento y la Rib. del Bezelga. In: Cruz, A.R., Oosterbeek, L., Reis, R.P. (Eds.), Arkeos 4, Quaternário e Pré-História do Alto Ribatejo (Portugal) CEIPHAR, pp. 59-144.

Corral, I., 1998b. Secciones com material arqueológico en estrato en las proximidades de Atalaia. In: Cruz, A.R., Oosterbeek, L., Reis, R.P. (Eds.), Arkeos 4 Quaternário e Pré-História do Alto Ribatejo (Portugal). CEIPHAR, pp. 227-250. 
Costa, F., 1984. Os terraços do vale do Tejo entre os rios Torto e Alviela. Notas geomorfológicas. Master Thesis. Univ. Lisboa, p. 152.

Cristiani, E., Cura, S., Grimaldi, S., Gomes, J., Oosterbeek, L., Rosina, P., in press. Functional analysis and experimental archaeology: the Middle Pleistocene site of Ribeira da Atalaia, (Central Portugal). Proceedings of the Workshop on "Recent Functional Studies on Non-Flint Stone Tools, Methodological Improvements and Archaeological Inferences", Lisbon, 2008, electronic edition: http:// www.workshop-traceologia-lisboa2008.com/artigos/Cristiani_Cura_A_FUNCTIONAL ANALYSIS.pdf.

Cunha, P.P., 1992. Estratigrafia e sedimentologia dos depósitos do Cretácico Superior e Terciário de Portugal Central, a leste de Coimbra. PhD Thesis. Univ. Coimbra, p. 262

Cunha, P.P., Barbosa, B.P., Reis, R.P., 1993. Synthesis of the Piacenzian onshore record, between the Aveiro and Setúbal parallels (western Portuguese margin). Ciências da Terra 12, 35-43.

Cunha, P.P., Martins, A.A., Daveau, S., Friend, P.F., 2005. Tectonic control of the Tejo river fluvial incision during the late Cenozoic, in Ródão - central Portugal (Atlantic Iberian border). Geomorphology 64, 271-298

Cunha, P.P., Martins, A.A., Huot, S., Murray, A., Raposo, L., 2008. Dating the Tejo Rive lower terraces in the Ródão area (Portugal) to assess the role of tectonics and uplift. Geomorphology 102, 43-54

Cura, S., Grimaldi, S., 2009. The intensive quartzite exploitation in Midlle Tagus Valley Pleistocene open air sites - the example of Ribeira da Ponte da Pedra. Technological analysis on quartzite exploitation. Workshop 15. Proceedings ArchaeoPress, BAR-International Series. UISPP.

Daveau, S., 1993. Terraços fluviais e litorais. In: O Quaternário em Portugal, Balanço e perspectivas, Colibri, pp. 17-28.

Dias, J.A., Boski, T., Rodrigues, A., Magalhães, F., 2000. Coastline evolution in Portugal since the Last Glacial Maximum until present-a synthesis. Marine Geology 170 177-186.

Dias, M.I., Prudêncio, M.I., Franco, D., Cura, S., Grimaldi, S., Oosterbeek, L., Rosina, P., 2009. Luminescence dating of a fluvial deposit sequence: Ribeira da Ponte da Pedra - Middle Tagus Valley, Portugal. In: Dias, M.I., Prudêncio, M.I. (Eds.), Archaeometry - Proceedings of the XV UISPP Congress. Oxford, BAR, pp. 103113.

Gonçalves, F., Zbyszewski, G., Carvalhosa, A., Coelho, A.P. 1979. Notícia Explicativa da Folha 27-D (Abrantes), Carta Geológica de Portugal na escala de 1/50000. Serviços Geológicos de Portugal, p. 75.

Grimaldi, S., Rosina, P., Corral, I., 1998. Interpretazione Geo-Archeologica di alcune industrie litiche "Languedocensi" del Medio Bacino del Tejo. In: Cruz, A.R., Oosterbeek, L., Reis, R.P. (Eds.), Arkeos 4 Quaternário e Pré-História do Alto Ribatejo (Portugal). CEIPHAR, pp. 145-226.

Grimaldi, S., Rosina, P., Cruz, A.R., Oosterbeek, L., 1999a. A geo-archaeological interpretation of some "Languedocian" lithic collections of the Alto Ribatejo (Central Portugal). In: Cruz, A.R., Milliken, S., Oosterbeek, L., Peretto, C. (Eds.), Arkeos 5, Human Population Origins in the Circum-Mediterranean Area. CEIPHAR, pp. 231-241.

Grimaldi, S., Rosina, P., Boton Garcia, F., 1999b. A behavioral perspective on "archaic" lithic morphologies in Portugal: the case of Fonte da Moita open air site. Journal of Iberian Archaeology. ADECAP 1, 33-57.

Grimaldi, S., Rosina, P., Boton, F., 2000. Um sítio ao ar livre do Plistoceno Médio no Alto Ribatejo (Portugal): Fonte da Moita. Proceedings of $3^{\circ}$ Congresso de Arqueologia Peninsular, Porto. ADECAP 2, 123-131.

Grimaldi, S., Rosina, P., 2001. O Pleistoceno Médio Final no Alto Ribatejo (Portuga central): o sítio da Ribeira da Ponte da Pedra. In: Cruz, A.R., Oosterbeek, L. (Eds.), Arkeos 11, Territórios, mobilidade e povoamento no Alto-Ribatejo. II: Santa Cita e o Quaternário da região. CEIPHAR, pp. 89-116.

Gutiérrez-Elorza, M., García-Ruiz, J.M., Goy, J.L., Gracia, F.J., Gutiérrez-Santolalla, F. Martí, C., Martín-Serrano, A., Pérez-González, A., Zazo, C., Aguirre, E., 2002. Quaternary. In: Gibbons, W., Moreno, T. (Eds.), The Geology of Spain. The Geological Society, pp. 335-366.

Huntley, D.J., Baril, M.R., 1997. The K content of the K-feldspars being measured in optical dating or in thermoluminescence dating. Ancient TL 15, 11-13.

Huot, S., Lamothe, M., 2003. Variability of infrared stimulated luminescence properties from fractured feldspar grains. Radiation Measurements 37 . 499-503.

Jaime, A., 2002. Contribuition a l'étude de l'industrie de Fonte da Moita (Vila Nova da Barquinha, Alto Ribatejo, Portugal). In: Cruz, A.R., Oosterbeek, L. (Eds.), Arkeos 13. Territórios, mobilidade e povoamento no Alto-Ribatejo. IV: Contextos macrolíticos. CEIPHAR, pp. 56-110.

Lamothe, M., Auclair, M., Hamzaoui, C., Huot, S., 2003. Towards a prediction of longterm anomalous fading of feldspar IRSL. Radiation Measurements 37, 493-498.

Leopold, L.B., Wolman, M.G., Miller, J.P., 1964. Fluvial Processes in Geomorphology. Freeman, W.H., S. Francisco, p. 522

Lemorini, C., Grimaldi, S., Rosina, P., 2001. Observações funcionais e tecnológicas num habitat Paleolítico: Fonte da Moita (Portugal central). In: Cruz, A.R.,Oosterbeek, L (Eds.), Arkeos 11, Territórios, mobilidade e povoamento no Alto-Ribatejo. II: Santa Cita e o Quaternário da região. CEIPHAR, pp. 117-140.

Lussu, T., Rosina, P., Oosterbeek, L., Costa, F. 2001. O Musteriense de Santa Cita (Tomar, Alto Ribatejo, Portugal): investigação e conservação. In: Cruz, A.R., Oosterbeek, L. (Eds.), Arkeos 11, Territórios, mobilidade e povoamento no Alto-Ribatejo. II: Santa Cita e o Quaternário da região. CEIPHAR, pp. 13-70.

Martins, A.A., 1999. Caracterização morfotectónica e morfossedimentar da Bacia do Baixo Tejo (Pliocénico e Quaternário). PhD Thesis. Univ. Évora, p. 500.

Martins, A.A., Barbosa, B.P., 1992. Planaltos do Nordeste da Bacia Terciária do Tejo (Portugal). Comunicações dos Serviços Geológicos de Portugal 78 (1), 13-22.
Martins, A.A., Cunha, P.P., Huot, S., Murray, A., Buylaert, J.P., 2009a. Geomorphological correlation of the tectonically displaced Tejo river terraces (Gavião-Chamusca area, Portugal) supported by luminescence dating. Quaternary International 199, 75-91.

Martins, A.A., Cunha, P.P., Buylaert, J.P., Huot, S., Murray, A., Dinis, P., Stokes, M. 2009b. K-feldspar IRSL dating of a Pleistocene river terrace sequence of the Lower Tejo River (Portugal, western Iberia). Quaternary Geochronology, doi:10.1016/j.quageo.2009.06.004

Mozzi, P., 1998. Evoluzione Geomorfologica della Bassa Valle del Fiume Nabão. In: Cruz, A.R., Oosterbeek, L., Reis, R.P. (Eds.), Arkeos 4, Quaternário e Pré-História do Alto Ribatejo (Portugal). CEIPHAR, pp. 37-58.

Mozzi, P., Raposo, L., Cruz, A.R., Oosterbeek, L., Reis, R.P., 1999. Morpho-stratigraphy of Quaternary deposits and the archaeological record: the case of the Tejo and Nabão valleys (Ribatejo, Portugal). In: Cruz, A.R., Milliken, S., Oosterbeek, L., Peretto, C. (Eds.), Arkeos 5, Human Population Origins in the Circum Mediterranean Area: Adaptations of the Hunter-gatherer Groups to Environmental Modifications. CEIPHAR, pp. 63-84

Mozzi, P., Azevedo, T., Nunes, E., Raposo, L., 2000. Middle terrace deposits of the Tagus river in Alpiarça. Portugal, in relation to early human occupation. Quaternary Research 54, 359-371.

Murray, A.S., Wintle, A.G., 2000. Luminescence dating of quartz using an improved single-aliquot regenerative-dose protocol. Radiation Measurements 32, 57-73.

Murray, A., Marten, R., Johnston, A., Martin, P., 1987. Analysis for naturally occurring radionuclides at environmental concentrations by gamma spectrometry. Journal of Radioanalytical and Nuclear Chemistry 115, 263-288.

Oosterbeek, L., Cruz, A.R., Cura, S., Rosina, P., Grimaldi, S., Gomes, J., 2004. Ribeira da Ponte da Pedra: relatório da campanha de escavação de 2003. Techne. Arqueojovem, vol. 9. pp. 21-54.

Oosterbeek, L., Cura, S., Rosina, P., Grimaldi, S., Cruz, A.R., Gomes, J., in press. Cadre géochronologique et stratégies de gestion du territoire des cultures du Pléistocène Inférieur et Moyen dans la vallée du Tage (Portugal), L'Anthropologie.

Ortiz, J.E., Torres, T., Delgado, A., Reyesb, E., Díaz-Bautista, A., 2009. A review of the Tagus river tufa deposits (central Spain): age and palaeoenvironmental record. Quaternary Science Reviews 28, 947-963.

Reis, R.P., 1998. Estratigrafia e controlos deposicionais dos terraços fluviais quaternários, na região de Tomar-Entroncamento. In: Cruz, A.R., Oosterbeek, L., Reis, R.P. (Eds.), Arkeos 4, Quaternário e Pré-História do Alto Ribatejo (Portugal). CEIPHAR, pp. 21-35.

Pérez-González, A., 1994. Depresión del Tajo. In: Gutiérrez-Elorza, M. (Ed.), Geomorfología de España. Editorial Rueda, pp. 389-436.

Raposo, L., 1986. Mustierense. Mustiero-Languedocence ou Languedocense? Arqueologia 14, 13-21.

Raposo, L., 1987. Os mais antigos vestígios de ocupação humana paleolítica na região de Ródão. In: Da Pré-História à História, homenagem a O. Veiga Ferreira, Editorial Delta, pp. 153-178.

Raposo, L., 1995a. O Paleolítico. In: Medina, J. (Ed.), História de Portugal, vol. 1. Clube Internacional do Livro, pp. 23-85.

Raposo, L., 1995b. Ambientes, territórios y subsistência en el Paleolítico Médio de Portugal. Complutum 6, 57-77.

Raposo, L., 2000. The Middle-Upper Palaeolithic transition in Portugal. In: Stringer, C., Barton, R.N.E., Finlayson, C. (Eds.), Neanderthals on the Edge: 150th Anniversary Conference of the Forbes' Quarry Discovery, Gibraltar. Oxbow Books, Oxford, pp. 95-109.

Raposo, L., 2002. Um século de estudos no Paleolítico Médio em Portugal: balanço e perspectivas. Arqueologia e História 54, 25-39.

Raposo, L., Carreira, J.R., Salvador, M., 1985. A estação Acheulense final de Milharós, Vale do Forno, Alpiarça. Proceedings of I Reunião do Quaternário Ibérico 2, 41-60.

Ribeiro, J.C., 1990. Os primeiros habitantes. In: Serrão, J., Marques, A. (Eds.), Nova História de Portugal, vol. 1. Editorial Presença, pp. 15-74.

Ribeiro, O., 1943. Novas observações geológicas e morfológicas nos arredores de Vila Velha de Ródão, vol. 32. Publicações do Museu e Laboratório Mineralógico e Geológico da Faculdade de Ciências do Porto, pp. 1-24.

Roche, J., 1971. Le climatet les faunes du Paléolithique Moyen et Supérieure de la province d'Estremadura. Actas do II Congresso Nacional de Arqueologia, vol. 1. Ministério da Educação Nacional. Junta Nacional da Educação, pp. 39-50.

Rosina, P., 2002. Stratigraphie et géomorphologie des terrasses fluviatiles de la moyenne Vallée du Tage (Haut Ribatejo, Portugal). In: Cruz, A.R., Oosterbeek, L. (Eds.), Arkeos 13, Territórios, mobilidade e povoamento no Alto-Ribatejo. IV: Contextos macrolíticos. CEIPHAR, pp. 11-52.

Roucoux, K.H., de Abreu, L., Shackleton, N.J., Tzedakis, P.C., 2005. The response of NW Iberian vegetation to North Atlantic climate oscillations during the last 65 kyr. Quaternary Science Review 24, 1637-1653.

Santisteban, J., Schulte, L., 2007. Fluvial networks of the Iberian Peninsula: a chronological framework. Quaternary Science Reviews 26, 2738-2757.

Santonja, M., Pérez-González, A., 2000-2001. El Paleolítico inferior en el interior de la Península Ibérica. Un punto de vista desde la geoarqueología. Zephyrus 53$54,27-77$.

Shackleton, N.J., Berger, A., Peltier, W.R., 1990. An alternative astronomical calibration of the Lower Pleistocene timescale based on ODP site 677. Transactions of the Royal Society of Edinburgh 81, 252-261.

Silva, P.G., 2003. El Cuaternario del valle inferior del Manzanares (Cuenca de Madrid, España). Estudios Geológicos 59, 107131.

Silva, P.G., Canãveras, J.C., Zazo, C., Sánchez-Moral, S., Lario, J., Sanz, E., 1997. 3D softsediment deformation structures: existence for Quaternary seismicity in the Madrid basin, Spain. Terra Nova 9, 208-212. 
Silva, P.G., Zazo, C., Bardají, T., Baena, J., Lario, J., Rosas, A., 2009. Tabla Cronoestratigráfica del Cuaternario de la Península Ibérica. AEQUA, http://www.aequa.es/.

Van der Schriek, T., Passmore, D.G., Rolão, J., Stevenson, A.C., 2007. Estuarine-fluvial floodplain formation in the Holocene Lower Tagus valley (Central Portugal) and implications for quaternary fluvial system evolution. Quaternary Science Reviews 26, 2937-2957.

Vis, G., 2009. Fluvial and Marine sedimentation at a passive continental margin. The late Quaternary Tagus depositional system. PhD thesis. Vrije Univ., 244 pp.

Vis, G., Kasse, C., Vandenberghe, J., 2008. Late Pleistocene and Holocene palaeogeography of the Lower Tagus Valley (Portugal): effects of relative sea level, valley morphology and sediment supply. Quaternary Science Reviews 27, 1682-1709.

Wallinga, J., Bos, A.J.J., Dorenbos, P., Murray, A.S., Schokker, J., 2007. A test case for anomalous fading correction in IRSL dating. Quaternary Geochronology 2 , 216-221.

Wright, J.D., 2000. Global climate change in Marine Stable Isotope Records. In: Stratton Noler, J., Sowers, J.M., Lettis, W.R. (Eds.), Quaternary Geochronology. Methods and Applications. pp. 427-433.
Zbyszewski, G., 1943. La classification du Paléolithic ancien et la chronologie du Quaternaire de Portugal en 1942. Boletim da Sociedade Geológica de Portugal 2 (2-3), 111.

Zbyszewski, G., 1946. Étude géologique de la region d'Alpiarça. Comunicações dos Servicos Geológicos de Portugal XXVII, 145-268.

Zbyszewski, G., 1953. Carta Geológica de Portugal na escala 1:50,000 Notícia Explicativa da Folha 31-A Santarém. Serviços Geológicos de Portugal 16.

Zbyszewski, G., 1958. Le Quaternaire du Portugal. Boletim da Sociedade Geológica de Portugal 12, 1-227.

Zbyszewski, G., Carvalhosa, A., 1984. Carta Geológica de Portugal na escala 1:50,000, Notícia Explicativa da Folha 31-D Montargil. Serviços Geológicos de Portugal, p. 56.

Zilhão, J., 1997a. O Paleolítico Superior da Estremadura portuguesa, vol. I. Edições Colibri, Lisboa, p. 309.

Zilhão, J., 1997b. O Paleolítico Superior da Estremadura portuguesa, vol. II. Edições Colibri, Lisboa, p. 850. 